\title{
Alteration of As-bearing phases in a small watershed located on a high grade arsenic-geochemical anomaly (French Massif Central)
}

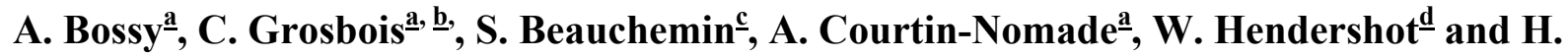 \\ Bril $^{\mathbf{a}}$ \\ ${ }^{a}$ Université de Limoges, GRESE EA 4330, F.S.T., 123 av. Albert Thomas, 87060 Limoges \\ cedex, France \\ ${ }^{\mathrm{b}}$ Université François Rabelais de Tours, UMR 6113 CNRS ISTO, Parc de Grandmont, 37000 \\ Tours cedex, France \\ ${ }^{\mathrm{c}}$ Natural Resources Canada, CANMET-MMSL, 555 Booth, Ottawa, Canada K1A 0G1 \\ ${ }^{\mathrm{d}}$ McGill University, 21111 Lakeshore, Ste Anne-de-Bellevue, Canada H9X 3V9
}

\begin{abstract}
At a watershed scale, sediments and soil weathering exerts a control on solid and dissolved transport of trace elements in surface waters and it can be considered as a source of pollution. The studied subwatershed $\left(1.5 \mathrm{~km}^{2}\right)$ was located on an As-geochemical anomaly. The studied soil profile showed a significant decrease of As content from $1500 \mathrm{mg} \mathrm{kg}^{-1}$ in the 135 $165 \mathrm{~cm}$ deepest soil layer to $385 \mathrm{mg} \mathrm{kg}^{-1}$ in the upper $0-5 \mathrm{~cm}$ soil layer. Directly in the stream, suspended matter and the $<63 \mu \mathrm{m}$ fraction of bed sediments had As concentrations greater than $400 \mathrm{mg} \mathrm{kg}^{-1}$. In all these solid fractions, the main representative As-bearing phases were determined at two different observation scales: bulk analyses using X-ray absorption structure spectroscopy (XAS) and microanalyses using scanning electron microscope (SEM) and associated electron probe microanalyses (EPMA), as well as microRaman spectroscopy and synchrotron-based micro-scanning X-ray diffraction ( $\mu$ SXRD) characterization. Three main As-bearing phases were identified: (i) arsenates (mostly pharmacosiderite), the most concentrated phases As in both the coherent weathered bedrock and the 135-165 cm soil layer but not observed in the river solid fraction, (ii) Feoxyhydroxides with in situ As content up to $15.4 \mathrm{wt} . \%$ in the deepest soil layer, and (iii) aluminosilicates, the least concentrated As carriers. The mineralogical evolution of Asbearing phases in the soil profile, coupled with the decrease of bulk As content, may be related to pedogenesis processes, suggesting an evolution of arsenates into As-rich Feoxyhydroxides. Therefore, weathering and mineralogical evolution of these As-rich phases may release As to surface waters.
\end{abstract}

\section{Introduction}

In surface environments, As can be released from two solid sources: (i) natural weathering processes of As-rich bedrock, soil and sediment and (ii) anthropogenic solid inputs related to mining, agricultural and industrial activities ([Fergusson, 1990], [Nriagu, 1994] and [Smedley and Kinniburgh, 2002]) where As concentrations can reach several weight percent in local soils and sediments ([Fergusson, 1990], [Baize, 1997] and [Smedley and Kinniburgh, 2002]). More specifically, Au-mining activities are usually located in As-rich areas and associated As-contaminated wastes can be dispersed by aerial and hydrological processes ([Mok and Wai, 1990], [Moore and Luoma, 1990], [Reimann et al., 2000] and [Courtin-Nomade et al., 
2005]). When these wastes react with runoff, surface and rain waters, they can damage ecosystems as As can be transferred to the dissolved fraction. For example, studies on fish collected in a mining area ([Foley et al., 1978], [Orsini et al., 1994], [Casiot et al., 2009] and [Vicente-Martorell et al., 2009]) revealed As concentrations higher than the quality standards (maximum As concentration in whole fish $<1 \mathrm{mg} \mathrm{kg}^{-1}$ wet weight according to WHO, 2001). On the other hand, natural attenuation processes can occur and dissolved As is frequently trapped by coprecipitation/sorption reactions with Fe, Mn and Al-oxyhydroxides, complexed with humic substances and/or immobilized by microbial activities ([Hoins et al., 1993], [Ali and Dzombak, 1996] and [Morin and Calas, 2006]).

In soils and sediments, primary As carriers are usually sulfides (e.g. arsenopyrite) and ferric arsenates like scorodite, pharmacosiderite, arseniosiderite ([Dove and Rimstidt, 1985], [Jones et al., 1997], [Roussel et al., 1999], [Morin et al., 2002], [O’Day, 2006] and [Cancès et al., 2008]). They are among the most concentrated As solid phases with Fe/As molar ratios $<1.5$ in a natural context ([Smedley and Kinniburgh, 2002], [Paktunc et al., 2004] and [O'Day, 2006]). The resistance of these As-bearing phases to weathering during particle transport depends on their mineralogical structure ([Craw et al., 2003] and [Paktunc et al., 2003]). Primary As-rich phases may evolve into As-rich secondary minerals like phosphates and sulfates ([Baur and Onishi, 1969] and [Boyle and Jonasson, 1973]) or be trapped by Feoxyhydroxides with molar Fe/As ratios ranging between 1.5 and 17 in natural and mining environments ([Morin et al., 2002], [Paktunc et al., 2004] and [Morin and Calas, 2006] and references therein). These Fe-oxyhydroxides have a large range of As concentrations and a greater adsorption capacity than Mn- or Al-oxyhydroxides ([De Vitre et al., 1991], [Sullivan and Aller, 1996] and [Lin and Puls, 2003]). Released As is also often sorbed on clay minerals ([Lin and Puls, 2000] and [Goldberg, 2002]).

The present study site is located in the Saint-Yrieix-la-Perche Au mining district which is characterized by an elevated geochemical background in As with average As concentrations of $120 \mathrm{mg} \mathrm{kg}^{-1}$ in soils (Chéry and Gateau, 1998), $70 \mathrm{mg} \mathrm{kg}^{-1}$ in $<63 \mu \mathrm{m}$ sediments (Grosbois et al., 2007) and $9 \pm 2 \mu \mathrm{g} \mathrm{L}^{-1}$ in surface waters (Grosbois et al., 2009). In this context, soil and sediment weathering can be a non-point source of As-enrichment. The objectives of this study were to identify the different As-bearing phases and to determine their spatial distribution in order to evaluate their fate during pedogenesis and solid transport. Three complementary approaches were employed to characterize the As-bearing phases in order to: (i) establish the spatial distribution of As with bulk chemical analyses, (ii) identify the As oxidation state and quantify relative proportions of the main As-bearing phases (bulk XANES-EXAFS spectroscopy) and (iii) characterize the main phases at a grain scale (SEM, EPMA, Raman and $\mu$-XRD techniques).

\section{Description of the site}

The Au mining district of Saint-Yrieix-la-Perche is located in SW France in the Garonne Basin (Fig. 1). The Au mineralization consists of quartz veins with $\mathrm{Au}-\mathrm{As}-\mathrm{S}$ minerals and native $\mathrm{Au}$ in quartz linked to a two-stage hydrothermal replacement event in granites, and ortho- and para-gneiss (Floc'h, 1983). It was the second most productive Au mining district of France mainly exploited during the Roman age and the 20th century (Cauuet, 1999). Thirtyseven tonnes of $\mathrm{Au}$ were extracted and 3 million tonnes of mining wastes were produced, including tailings and mining waste deposits (Nicaud, 2001). The mineralogical composition of these wastes are mostly quartz (more than $80 \%$ ), sulfides (mainly pyrite and arsenopyrite with some sphalerite, galena and stibnite), micas and clays such as illite, smectites and 
kaolinite (Roussel et al., 2000). This mineralogical association was also observed in bed sediments of the main river draining the mining district (Upper Isle river) despite the very low occurrence of sulfides (Grosbois et al., 2007).

The studied stream is a tributary of the Upper Isle river with a small subwatershed of $1.5 \mathrm{~km}^{2}$ (Fig. 1). It is located at an altitude between 300 and $375 \mathrm{~m}$ with a mean slope of $10 \%$. It is typical of a natural site located within the geochemical anomaly but no Au-vein exploitation was undertaken, only exploration galleries were excavated (maximum length of $70 \mathrm{~m}$ with no connection with the studied stream; Andres, 2007; pers. com.). During the low flow period, ochreous deposits are present in a wetland, upstream of the largest pond. They are identified as ferrihydrite containing up to $0.7 \mathrm{wt} \%$ of As (Bossy et al., work in progress). They appear when sub-anoxic groundwaters of the adjoining aquifer are probably the main inflow into the stream, containing $\mathrm{Fe}(\mathrm{II})$ which is oxidized to $\mathrm{Fe}(\mathrm{III})$ and then precipitated as ferrihydrite.

The studied area is $70 \%$ forested with $90 \%$ deciduous (mainly Castanea sativa) and $10 \%$ coniferous (mainly Pinus silvestris) trees. In the Upper Isle river basin, the spatial distribution of As in superficial soil horizons is relatively homogeneous over the mineralized veins which were emplaced between 317 and $290 \mathrm{Ma}$ (Bouchot et al., 2005). The As concentrations range from 250 to $500 \mathrm{mg} \mathrm{kg}^{-1}$ (Itard, 2007; pers. com.), which is 2-3 times higher than the soil background in this area (Chéry and Gateau, 1998). This basin is mainly characterized by Alocrisol and Arenosol-type soils developed on a metamorphic series formed of micaceous paragneiss-schist and orthogneiss (lower unit of the Limousin gneisses) with the presence of granitic bands ([Floc'h, 1983] and [Bouchot et al., 1989]).

The climate of the area is continental oceanic with mean air temperature of $5{ }^{\circ} \mathrm{C}$ in winter and $19^{\circ} \mathrm{C}$ in summer (years 2007-2008, database from climatheque.meteo.fr) and annual precipitation of $1349 \mathrm{~mm}$ in 2007 and $1279 \mathrm{~mm}$ in 2008 (database from climatheque.meteo.fr). The rainfall $\mathrm{pH}$ is $5.6 \pm 0.9(n=23$, this study) and runoff water $\mathrm{pH}$ is $5.1 \pm 0.5(n=13$, this study). The average annual discharge was $46 \mathrm{dm}^{3} \mathrm{~s}^{-1}(n=47$, this study) ranging from $11 \mathrm{dm}^{3} \mathrm{~s}^{-1}$ in July 2008 to $136 \mathrm{dm}^{3} \mathrm{~s}^{-1}$ in March 2007.

\section{Materials and methods}

\subsection{Sample collection and preparation}

Soil sampling was carried out in December 2006 (Fig. 1). A $165 \mathrm{~cm}$ deep soil profile was sampled on a hill top (360 $\mathrm{m}$ high) in a forested area in order to minimize lateral inputs of trace elements. The soil was developed as a 2-m thick profile overlying a granite saprolite which lays deeper than $4 \mathrm{~m}$ below the surface. Therefore, the bedrock could not be observed in situ but coherent bedrock was sampled at the surface close to the soil profile. It was a partly weathered leucogranite.

In the field, composite samples of each layer were collected in polypropylene bags for soil $\mathrm{pH}$, major and trace element analyses as well as for As solid speciation analyses. The soil was not hydromorphic and was well drained throughout its profile due to its coarse texture and location on a slope. Therefore, no special handling was deemed necessary to preserve the As oxidation state. In the laboratory, these samples were air-dried, gently crushed in an acid precleaned agate mortar to break soil aggregates and sieved on $2 \mathrm{~mm}$ Nylon mesh to remove coarse fragments (mainly organic material). Samples of coherent weathered bedrock were also crushed and sieved on $200 \mu \mathrm{m}$ Nylon mesh. 
Sampling of bed sediments was carried out on June 2007 in the main stream (Fig. 1). Sediments were collected at two depths $(0-5 \mathrm{~cm}$ and 5-20 cm layers) with clean scoops and stored in polypropylene bottles for major and trace element analyses. For As solid speciation determination, additional cores were sampled, stored in an icebox during transport and frozen immediately on arrival in the laboratory in order to better keep the anoxic layer. In the laboratory, both layers were then freeze-dried and sieved on $63 \mu \mathrm{m}$ Nylon mesh in order to limit grain-size effects on As bulk concentrations ([Horowitz, 1991] and [Thomas and Meybeck, 1992]).

Suspended matter in surface waters was sampled regularly every 15 days from October 2006 to September 2007 and with an automatic sampling system (SIGMA 900) from October 2007 to December 2008 at the outlet of the subwatershed (Fig. 1). The collection consisted of eight sub-samples of $120 \mathrm{~mL}$ over $24 \mathrm{~h}$ (one sample every $3 \mathrm{~h}$ ) cumulated in $1 \mathrm{~L}$ acid precleaned polypropylene bottle. Each sample represents a 24 h-composite sample integrating daily variations in surface water composition. Control for particle sorption on bottle walls was performed according to Grosbois et al. (2009) and less than 10\% difference was observed for suspended matter concentrations. Suspended matter was separated by filtration of $250 \mathrm{~mL}$ through $0.2 \mu \mathrm{m}$ cellulose acetate filter (Sartorius) and then air-dried over $48 \mathrm{~h}$ under a hood. Major and trace element analyses have been carried out on 41 samples throughout the hydrological years 2006-2007 and until March 2008, although As solid speciation and in situ observations were specifically done on two samples representing respectively the high flow and low flow periods.

\subsection{Chemical analyses}

Soil $\mathrm{pH}$ was measured in deionized water with a soil/solution ratio of $1: 5$ according to NF ISO 10390 standard (agitation for $5 \mathrm{~min}$ and $\mathrm{pH}$ measured after standing for $2 \mathrm{~h}$ ). Organic $\mathrm{C}$ was determined after complete combustion at $1000{ }^{\circ} \mathrm{C}$ to $\mathrm{CO}_{2}$ in the presence of $\mathrm{O}_{2}$. Contents of $\mathrm{C}$ were quantified by gas chromatography and elemental analyser $\mathrm{CN}$ according to NF ISO 10694.

Bulk concentrations of major elements ( $\mathrm{Si}, \mathrm{Al}, \mathrm{Fe}, \mathrm{Mg}, \mathrm{Na}, \mathrm{K}, \mathrm{Ca}, \mathrm{Ti}$ ) in coherent weathered bedrock, soil and sediments were determined using lithium metaborate/tetraborate fusion of $0.2 \mathrm{~g}$ of crushed bedrock, $<2 \mathrm{~mm}$ dry soil and $<63 \mu \mathrm{m}$ sediment and then dissolved in $\mathrm{HNO}_{3}$ (NF ISO 14869-2). Analyses by ICP-ES (Spectro Ciros Vision) were performed at the ACME Analytical laboratories (Vancouver, Canada). Trace elements (As, Co, Cr, Mn, Ni, Pb, Zn, Zr) were determined by ICP-MS (Perkin Elmer 5000) after aqua regia total digestion of $0.5 \mathrm{~g}$ of material in the same laboratory. Reference materials like DS7 (a rock and soil mix, spiked with additional elements) and SO-18 (a basalt, rhyolite and granite mix) were used throughout the different analytical steps. Precision of analyses was better than $1 \%$ for major elements and better than $6 \%$ for trace elements (Table 1 ).

The total content of elements in suspended matter were determined using a multi-acid digestion $\left(\mathrm{HNO}_{3}-\mathrm{HCl}-\mathrm{HF}-\mathrm{HClO}_{4}\right)$ on dried filters in Teflon beakers heated at $150{ }^{\circ} \mathrm{C}$ for $3 \mathrm{~h}$ and digest solutions were diluted to $50 \mathrm{~mL}$ with $1.5 \% \mathrm{HCl}$. Major elements $(\mathrm{Al}, \mathrm{Fe}, \mathrm{Mg}, \mathrm{Na}$, $\mathrm{K}, \mathrm{Ca}, \mathrm{Ti}$ ) were measured by ICP-AES (Jobin Yvon Ultima 2) and trace elements (As, Co, Cr, $\mathrm{Mn}, \mathrm{Ni}, \mathrm{Pb}, \mathrm{Zn}, \mathrm{Zr}$ ) by ICP-MS (Thermo X S2) at the BRGM laboratory (Orléans, France). International reference materials like BEN (basalt) were used throughout the different analytical steps. Precision of analyses was better than $15 \%$ (Table 1). In addition, control for 
filter composition was performed and no major contribution was observed for all studied elements to the concentrations in suspended matter.

\subsection{Arsenic speciation analyses}

X-ray absorption structure spectroscopy was carried out at the As K-edge at the National Synchroton Light Source at Brookhaven National Laboratory (NSLS-BNL, New York) on the beamline X11A. The Si( $\left.\begin{array}{lll}1 & 1 & 1\end{array}\right)$ monochromator was calibrated using the inflection point in the spectrum for metallic Au foil at 11,919 eV. Air-dried, finely ground soil samples were mounted behind Kapton tape into a $380 \mu \mathrm{m}$ thick Teflon holder and were analyzed in fluorescence or transmission mode depending on As concentration. The energy scale for each sample was referenced to the edge in the Au metal spectrum collected in transmission mode simultaneously with sample data. Three to six scans were collected for each sample then merged.

The mean As oxidation state in the sediment and soil samples was determined by taking the K-edge inflection point defined as the first maximum peak in the first derivative of the normalized spectra. The As speciation was examined using both the X-ray absorption near edge structure (XANES) and the extended X-ray absorption fine structure (EXAFS) spectra. The XANES data were baseline-corrected and normalized using Athena 8.054 (Ravel and Newville, 2005). Background removal for the EXAFS (chi) spectra was done using a spline range from about $0.5-14 \AA^{-1}$. The chi data were cubic weighted $\left(\mathrm{k}^{3}\right)$ for fitting analysis. The As speciation was determined by least-squares fitting (LSF) using linear combinations of EXAFS spectra from reference compounds. Well characterized reference compounds were obtained from a previous study and included $\mathrm{As}_{2} \mathrm{O}_{5}, \mathrm{As}_{2} \mathrm{O}_{3}, \mathrm{As}_{2} \mathrm{~S}_{3}$, arsenopyrite and Caarsenate (Beauchemin and Kwong, 2006). Pharmacosiderite was obtained and characterized by Paktunc et al. (2004). Aluminum arsenate $\left(\mathrm{AlAsO}_{4} \cdot \mathrm{H}_{2} \mathrm{O}\right)$ and $\mathrm{Mn}$ arsenate $\left(\mathrm{Mn}_{3}\left(\mathrm{AsO}_{4}\right)_{2}\right)$ were synthesized according to protocols of Rochette et al. (1998) and Hess and Blanchar (1976), respectively. XRD analysis showed that both precipitates were amorphous. Two-line ferrihydrite with adsorbed $\mathrm{As}(\mathrm{V})\left(800 \mathrm{mmol} \mathrm{As} \mathrm{kg}{ }^{-1}\right)$ was synthesized at $\mathrm{pH}$ 5. The 2-line ferrihydrite was synthesized according to the procedure of Schwertmann and Cornell (1991). 2-line ferrihydrite with adsorbed As(III) $\left(601 \mathrm{mmol} \mathrm{kg}^{-1}\right)$ was synthesized according to the procedure of Burnol et al. (2007). Prior to LSF, principal component analysis (PCA) and target transformation were conducted on both the XANES (range -20 to $80 \mathrm{eV}$ ) and EXAFS $\left(k=3\right.$, range $2.8-11.5 \AA^{-1}$ for soils and $2.8-10 \AA^{-1}$ for sediments) data to get a preliminary insight on the most likely species present in the samples (Beauchemin et al., 2002). Based on the target analysis, five reference compounds were discarded and the least-squares fitting was conducted using all possible binary and ternary combinations of the remaining As standards. The fitting was first carried out on the EXAFS spectra and the reliability of the best fits was then tested on the XANES spectra. No constraint to sum to 1 was imposed during fitting. Fitting analysis was achieved using the Athena 8.054 software (Ravel and Newville, 2005).

\subsection{Physical and mineralogical characterization}

Mineralogy of each sediment and soil sample was determined on sample powder by X-ray diffraction $(\mathrm{XRD})$ using $\mathrm{Cu} \mathrm{Ka} 1_{2}$ radiation (step size $=0.02^{\circ} 2 \theta$, counting time $=10 \mathrm{~s} / \mathrm{step}$, between $3^{\circ}$ to $70^{\circ} 2 \theta$ ) on a Siemens D5000 diffractometer (University of Limoges).

Polished thin-sections of embedded material in epoxy resin were observed using a scanning electron microscope (SEM, Philips XL-30; University of Limoges) coupled to an energy 
dispersive X-ray system (EDS) with an accelerating voltage of $20 \mathrm{kV}$. Electron probe microanalyses (EPMA, Cameca SX 50; University of Orléans) were performed at $15 \mathrm{kV}$ with a beam current of $4 \mathrm{nA}$ corresponding to an analyzed sample volume of $1-2 \mu \mathrm{m}^{3}$. Standards like orthoclase to calibrate $\mathrm{K}$, albite $(\mathrm{Si}, \mathrm{Na})$, hematite $(\mathrm{Fe})$, andradite $(\mathrm{Ca})$, pyrophanite $(\mathrm{Ti}$, $\mathrm{Mn})$, corundum $(\mathrm{Al})$, chromite $(\mathrm{Cr})$, olivine $(\mathrm{Mg})$, barytine $(\mathrm{S}, \mathrm{Ba})$, apatite $(\mathrm{P})$, blende $(\mathrm{Zn})$, galena $(\mathrm{Pb})$, AsGa (As) were used. The characterization of As-bearing solid phases was completed by micro-Raman spectroscopy (Jobin Yvon 6400) with an $\mathrm{Ar}^{+}$laser $(514.5 \mathrm{~nm}$ ) as radiation source. Scans were collected with filter D1 (low energy output of laser, about 2$5 \mathrm{~mW}$, to avoid local heating of the sample) between 200 and $1400 \mathrm{~cm}^{-1}$ with a scan time of $10 \mathrm{~min}$. For particles with a small size, synchrotron-based micro X-ray diffraction ( $\mu$-XRD) patterns were collected at the Advanced Light Source at Lawrence Berkeley National Laboratory (ALS-LBNL; California, USA) on the beamline 12.3.2 (Kunz et al., 2009). The sample thin-sections were analyzed in reflection geometry using the monochromatic mode with incident energy of $10 \mathrm{keV}$ and a $1024 \times 1024$ pixels MAR CCD detector.

Monochromatic mode was preferred here, as the studied phases are smaller than $1 \mu \mathrm{m}$, using an incident X-ray energy of $10 \mathrm{keV}$, a beam size of $2 \mu \mathrm{m}(H) \times 20 \mu \mathrm{m}(V)$ (beam footprint size on the sample of $20 \mu \mathrm{m}(H) \times 20 \mu \mathrm{m}(V)$ FWHM) and a Mar133 CCD detector $(1 \mathrm{~K} \times 1 \mathrm{~K}$ pixels binned mode). The beam spot size was $2 \mu \mathrm{m} \times 2 \mu \mathrm{m}$ and the XRD patterns were obtained with an exposure time up to $400 \mathrm{~s}$ for each diffractogram. The sample thin-sections were fixed to an XYZ stage and inclined at a $6^{\circ}$ tilt to the incident $\mathrm{X}$-ray beam.

\section{Results and discussion}

\subsection{Bulk characterization of soil, sediment and suspended matter}

\subsubsection{General characteristics of studied soil, sediment and suspended matter}

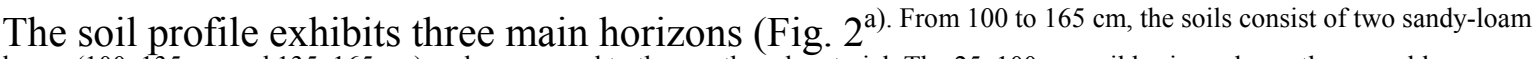
layers $(100-135 \mathrm{~cm}$ and $135-165 \mathrm{~cm})$ and correspond to the weathered material. The $25-100 \mathrm{~cm}$ soil horizon shows three weakly differentiated layers $(25-55 \mathrm{~cm}, 55-80 \mathrm{~cm}$ and $80-100 \mathrm{~cm}$ ) with an evolution of texture from sandy loam to loam upwards. The upper part of the soil profile is characterized by an organic horizon divided into two layers $(5-25$ and $0-5 \mathrm{~cm}$ ) with organic $\mathrm{C}$ content from 26.3 to $92.6 \mathrm{~g} \mathrm{~kg}^{-1}$. This soil is acidic with a $\mathrm{pH}_{\text {water }}$ ranging from 4.0 to 4.7 . The mineralogical assemblage is quite homogeneous with quartz and clay minerals like kaolinite and mica-type clay minerals (illite). In addition, the 135-165 cm soil layer includes amphiboles and chlorite. In the $<63 \mu \mathrm{m}$ bed sediments and suspended matter, quartz and clay minerals with the presence of chlorite were detected.

\subsubsection{Distribution of As in studied soil, sediments and suspended matter}

Major elements in the coherent weathered bedrock and in the soil profile are Si (274$\left.342 \mathrm{~g} \mathrm{~kg}^{-1}\right), \mathrm{Al}\left(68-112 \mathrm{~g} \mathrm{~kg}^{-1}\right), \mathrm{K}\left(24-44 \mathrm{~g} \mathrm{~kg}^{-1}\right)$ and Fe (11-18 $\mathrm{g} \mathrm{kg}^{-1}$; Table 1).

Throughout the vertical soil profile, concentrations of major elements are in the same range. Regarding trace elements, As is the most concentrated with $5660 \mathrm{mg} \mathrm{kg}^{-1}$ in the coherent weathered bedrock and has concentrations ranging from $1490 \mathrm{mg} \mathrm{kg}^{-1}$ in the $135-165 \mathrm{~cm}$ soil layer down to $385 \mathrm{mg} \mathrm{kg}^{-1}$ in the $0-5 \mathrm{~cm}$ soil layer. In order to evaluate the vertical evolution of As content in the soil profile, enrichment factor (EF) calculations have been carried out according to (Rahn and McCafrey, 1979) and (Kurtz et al., 2000) and Hill et al. (2000). Titanium was chosen as a conservative element in the soil profile, as bulk Ti concentrations are stable, ranging from $1.1 \mathrm{~g} \mathrm{~kg}^{-1}$ in the coherent weathered bedrock to $1.9 \mathrm{~g} \mathrm{~kg}^{-1}$ in the 0 
$5 \mathrm{~cm}$ soil layer. Furthermore Soubrand-Colin et al. (2005) have shown that Ti-bearing minerals like Fe-Ti oxides are stable during pedogenesis and weathering processes. EF were calculated using the following formula: $\operatorname{EF}(X)=\left([X]_{h} /[\mathrm{Ti}]_{h}\right) /\left([X]_{\mathrm{ref}} /[\mathrm{Ti}]_{\mathrm{ref}}\right)$ where $[X]_{h}$ and $[X]_{\text {ref }}$ are the respective concentration of the element $X$ in a soil layer and in the reference level (coherent weathered bedrock). The vertical distribution of EFs in the soil profile show that all trace elements except As have a conservative behavior during pedogenesis with $\mathrm{EF}$ ranging from 0.3 to 1.5 except $\mathrm{Co}$ and $\mathrm{Cr}(\mathrm{EF}>1.5)$ (Table 2). Cobalt and $\mathrm{Cr}$ enrichment factors $>1.5$ indicate (i) natural and/or anthropogenic contributions in addition to the elements derived from the bedrock, such as atmospheric deposition, pollution by drainage water and trapping of dissolved elements in the solid phases and/or (ii) relative enrichment due to the loss of mobile elements from the soil. Arsenic was the only depleted trace element with EF values ranging from 0.19 in the $135-165 \mathrm{~cm}$ soil layer down to 0.04 in the $0-5 \mathrm{~cm}$ soil layer. This As depletion could be related to a mixing effect with less enriched surface soil due to bioturbation in the upper layers, evolution and transformation of the As-rich phases during pedogenetic processes, and/or release and export of As, involving a change of the solid speciation.

Arsenic can be associated with Fe in sulfides (not observed at this site although sulfides are the most common phases in the Au veins), arsenates and oxyhydroxides ([Jones et al., 1997], [Manning and Goldberg, 1997] and [Roussel et al., 1999]). In this study, the molar Fe/As ratios increased from 2.7 in the coherent weathered bedrock to 44.4 in the $0-5 \mathrm{~cm}$ soil layer (Fig. 2b). As the EF of Fe in the soil profile is almost constant, the increase of Fe/As molar ratios confirms the As loss during pedogenesis.

The chemical composition of major elements in suspended matter and sediments is similar to that of soil (Table 1). In the suspended matter and in the $<63 \mu \mathrm{m}$ fraction of 5-20 cm and 0$5 \mathrm{~cm}$ sediment layers, major elements are $\mathrm{Si}$ (around $200 \mathrm{~g} \mathrm{~kg}^{-1}$ ) and $\mathrm{Al}$, with bulk concentrations ranging from 22 to $376 \mathrm{~g} \mathrm{~kg}^{-1}$ related to the mineralogical assemblage (Table 1). As observed in the soil profile, As is the most concentrated trace element in suspended matter and sediments with amounts ranging from 492 to $11,900 \mathrm{mg} \mathrm{kg}^{-1}$ in suspended matter and from $455 \mathrm{mg} \mathrm{kg}^{-1}$ in the $5-20 \mathrm{~cm}$ sediment layer up to $1650 \mathrm{mg} \mathrm{kg}^{-1}$ in the $0-5 \mathrm{~cm}$ sediment layer. Suspended matter has higher levels of $\mathrm{Fe}, \mathrm{Cr}, \mathrm{Zn}$ and $\mathrm{Pb}$, a similar content of $\mathrm{Co}$ and a lower concentration of $\mathrm{Zr}$ compared to the $0-5 \mathrm{~cm}$ sediment layer. With regard to the geochemical background defined in the $<63 \mu \mathrm{m}$ fraction of bed sediments of the area (Grosbois et al., 2007), As concentrations are 24 times higher in these bed sediments and from 7 to 170 times higher in the suspended matter collected in this subwatershed. The $<63 \mu \mathrm{m}$ bed sediments are also 2-10 times more concentrated in As than those located in the main river draining the mining district directly (160-890 $\mathrm{mg} \mathrm{kg}^{-1}$; Grosbois et al., 2007). In addition to the dilution effect downstream, this shows that, as with mine sources, weathering of the geochemical anomaly can also largely influence sediment composition.

\subsection{Arsenic solid speciation}

\subsubsection{XAS a nalysis of arsenic}

Arsenic speciation in the bulk samples was first determined using XAS spectroscopy in order to identify the main categories of As carriers. This would help to better target the As solid phases to determine using more sensitive and in situ methods at the grain scale. 
In the soil profile, XANES analysis indicates the dominance of oxidized As species, whatever the As contents. The first derivative As XANES spectra for the soil samples show a dominance of As(V) species (Fig. 3). In order to identify the main As species, the XANES and $\chi(k)^{*} k^{3}$ EXAFS data for the $135-165 \mathrm{~cm}$ and $0-5 \mathrm{~cm}$ soil layers were investigated with PCA, target analysis and quantitative fitting. Fitting was first performed on the $\chi(k){ }^{*} k^{3}$ EXAFS data because these spectra revealed more structural variation than the XANES data. The best fit obtained on the EXAFS spectrum was then tested on the XANES data.

For the 135-165 cm soil layer, As speciation could not be clearly resolved based on the As reference compounds available in the dataset. While the best $\chi(k)^{*} k^{3}$ fit would suggest that half of the As is As(V) bound to the Al phase (52\%) and the other half is $\mathrm{As}(\mathrm{V})$ associated to the Fe phase ( $48 \%$ of pharmacosiderite; Fig. $4 d$ ), this fit failed to predict the peak at $\approx 8.8 \AA^{-1}$ and could not adequately model the XANES or Fourier transform (FT) spectrum (data not presented). In Fig. $4 \mathrm{~b}$, the peak at $\approx 8.8 \AA^{-1}$ in the EXAFS data for the $135-165 \mathrm{~cm}$ soil layer is, nevertheless, characteristic of the pharmacosiderite (Morin et al., 2002). Compared to the 135-165 cm soil layer and the pharmacosiderite spectrum published by Morin et al. (2002), the pharmacosiderite reference compound appears to be of lower crystallinity and contains a non-negligible fraction of reduced As species detectable in its XANES spectrum (Fig. 4a). These features partly explain the misfit observed between the predicted and measured data. The presence of the Al phase would be supported by the FT of the 135-165 cm soil layer which shows a second shell peak at shorter distance than the As-Fe second shell of the FT for the pharmacosiderite or As(V) adsorbed on ferrihydrite (Fig. 4c), and this distance is more in line with the As-Al second shell reflecting the presence of an As-bearing Al phase, in addition to the pharmacosiderite. However, the very low crystallinity of the synthesized Al arsenate standard is likely to result in an overestimation of the contribution of the Al phases during the fitting analysis.

For the $0-5 \mathrm{~cm}$ soil layer, the XANES and EXAFS fitting shows that As is dominantly present as $\mathrm{As}(\mathrm{V})$ adsorbed on ferrihydrite $(>50 \%)$ and the remaining is partly accounted for by $\mathrm{As}(\mathrm{V})$ associated with an Al phase (Fig. 4d). These results are in agreement with FT which shows a radial distance for the second shell between those for As-Al and As-Fe, suggesting a contribution of both the Fe and Al phases. Despite the fitting limitations discussed above, the overall XAS fitting results for the soil indicate that $>90 \%$ of As is As(V) throughout the soil profile with a potentially small proportion of As(III) related to the ferrihydrite (15\%) in the 0 $5 \mathrm{~cm}$ soil layer sample according to its EXAFS fitting. The occurrence of As(III)-O species in the $0-5 \mathrm{~cm}$ soil layer sample would be supported by the first derivative XANES spectrum showing a visible shoulder in line with this oxidation state (Fig. 3).

In the sediment samples, the oxidation state of As varies depending on the redox environment in which the samples were collected. The first derivative As XANES spectrum for the $0-5 \mathrm{~cm}$ layer of sediment shows a dominance of $\mathrm{As}(\mathrm{V})$ species whereas the maximum peak of the first derivative As XANES spectrum for the 5-20 cm layer of the sediment is at a lower redox state in line with As(III)-O species (Fig. 3).

For the 5-20 $\mathrm{cm}$ sediment layer, both the XANES and the EXAFS fitting indicate that around half of the As is As(III) bound to ferrihydrite ( $>48 \%)$, more than one third is As(V) associated to the $\mathrm{Al}$ phase (34-41\%) and the remainder is explained by $\mathrm{As}_{2} \mathrm{~S}_{3}(11-15 \%)$ (Fig. 5b and d). The presence of a reduced As(III)-S species is supported by the first derivative XANES spectrum which shows a shoulder on the low energy side of the maximum peak, and this 
shoulder is in line with As(III)-S species (Fig. 3). However, the exact species might differ from $\mathrm{As}_{2} \mathrm{~S}_{3}$ reference compounds given that some misfit is observed on the low energy side of the XANES absorption peak for the predicted vs. measured data (Fig. 5a).

For the 0-5 cm sediment layer, XANES and EXAFS fitting shows that As is dominantly present as $\mathrm{As}(\mathrm{V})$ associated with ferrihydrite $(>56 \%)$ and the remaining is accounted for by As(III) adsorbed on ferrihydrite (Fig. 5d). These results are in agreement with field observations because reddish brown precipitates were commonly observed at the sediment surface of the wetland and were particularly abundant during drier periods. A small proportion of $\mathrm{As}(\mathrm{V})$ related to the Al phase (13\%) is also suggested by the EXAFS fitting of the $0-5 \mathrm{~cm}$ sediment sample but this phase is not significantly contributing to the XANES signal of the sediment and remains to be confirmed by in situ analysis. Overall, XANES and EXAFS fitting results for the sediments indicate that $>69 \%$ of the total As is As(V) in the 0 $5 \mathrm{~cm}$ sediment layer while As in the 5-20 cm sediment layer is in equal proportion between $\mathrm{As}(\mathrm{III})-\mathrm{O}$ and $\mathrm{As}(\mathrm{V})$ with the occurrence of a small fraction of As(III)-S.

\subsubsection{In situ arsenic-bearing phases analyses}

To complement the bulk As solid speciation, in situ As-bearing phase microanalyses were performed using SEM observations (qualitatively screened with BSE detector and EDS spectrum) and EPMA associated analyses (chemical composition of As-bearing phases). The mineralogical identification of these screened phases was completed by micro-Raman spectroscopy and synchrotron-based micro-scanning X-ray diffraction ( $\mu \mathrm{SXRD})$ characterization. This micro-analytical work allowed identification of four main types of Asbearing phases in the different solid compartments (coherent weathered bedrock, soil, sediments and suspended matter).

The most As-rich carriers are arsenates, mainly present in the coherent weathered bedrock and in the 135-165 cm soil layer (group I; Fig. 6). The size of arsenate particles ranges from 10 to $100 \mu \mathrm{m}$, usually smaller in the soil layer than in the bedrock. They also show various morphological aspects related to different alteration states (Fig. 7). In both the coherent weathered bedrock and in the 135-165 cm soil layer, in situ As concentrations have a similar range between 17.4 and 25.8 wt.\%. In situ Fe concentrations are slightly higher for arsenates in the bedrock than in this soil layer (Table 3) implying a higher in situ Fe/As molar ratio (respectively, ranging from 1.20 to 1.80 in 12 observed arsenate particles in the bedrock and from 1.15 to 1.38 in eight observed arsenate particles in the $135-165 \mathrm{~cm}$ soil layer). Barium concentrations were also detected in this type of As carrier, ranging from 3.91 to $5.88 \mathrm{wt} \%$ in the bedrock arsenates and from 5.03 to $7.49 \mathrm{wt} . \%$ in the $135-165 \mathrm{~cm}$ soil layer arsenates.

According to micro-Raman spectroscopy (Fig. 7), all these arsenates belong to the Fepharmacosiderite group $\left[(\mathrm{Ba}, \mathrm{Na}, \mathrm{K}) \mathrm{Fe}_{4}\left(\mathrm{AsO}_{4}\right)_{3}(\mathrm{OH})_{3} \cdot 6 \mathrm{H}_{2} \mathrm{O}\right]$ ([Mutter et al., 1984] and [Filippi et al., 2007]). All the spectra have a well-defined peak at $479 \mathrm{~cm}^{-1}$ (AsO stretching region, ascribed to bending $v_{4}$ mode) and broader peaks at $795 \mathrm{~cm}^{-1}$ (ascribed to the $\mathrm{OH}$ deformation vibration) and $884 \mathrm{~cm}^{-1}$ with a shoulder at $865 \mathrm{~cm}^{-1}$ (assigned to the $v_{3}$ vibrational modes) ([Frost and Kloprogge, 2003] and [Frost et al., 2009]). Less altered grains display better defined spectra with higher intensity compared to spectra of altered grains (Fig. 7). Given that all spectra showed the strongest peak at $479 \mathrm{~cm}^{-1}$, being intermediate in comparison with reference of pure pharmacosiderite $\left(475 \mathrm{~cm}^{-1}\right)$ and pure bariopharmacosiderite $\left(491.5 \mathrm{~cm}^{-1}\right)$ spectra $(n=8)$, these grains were identified as Ba-rich pharmacosiderite, and EPMA analyses showed that they contained very low in situ $\mathrm{K}$ and $\mathrm{Na}$ 
concentrations ( $<1.5 \mathrm{wt} . \%$ and $<0.6 \mathrm{wt} . \%$, respectively; Table 3$)$. A possible explanation for the peak shifting could be that the pharmacosiderite contained higher in situ Na contents, underestimated by EPMA analyses since $\mathrm{Na}^{+}$generally diffuses under the beam and is difficult to measure with EPMA techniques. Moreover, the peak shifting could also be due to the fact that all the reference spectra have been acquired using a He-Ne laser ([Frost and Kloprogge, 2003] and [Frost et al., 2009]) whereas an $\mathrm{Ar}^{+}$laser was used in this study. This Ba-rich character of pharmacosiderite was also observed by Morin et al. (2002), in a soil developed over another As-geochemical anomaly. In the bedrock, the presence of Ba-rich pharmacosiderite having pseudomorphic structure could be related to alteration of As sulfides like arsenopyrite (FeAsS) or other phases like löllingite (FeAs 2 ) ([Morin et al., 2002] and [Drahota et al., 2009]) but in the case of the present study, none of these primary minerals were observed in situ and löllingite has never been reported in studies of the mineralogy of materials from this area.

The most observed As-bearing phases are Fe-oxyhydroxides (group II; Fig. 6) containing up to $3.1 \mathrm{wt} . \%$ of As and up to $75.5 \mathrm{wt} . \%$ of Fe (Table 3). They are present throughout the soil profile and in sediments (Fig. 6). Their size is variable, from $20 \mu \mathrm{m}$ to $400 \mu \mathrm{m}$. They have a fluffy appearance with irregular forms. In the $0-5 \mathrm{~cm}$ soil layer, Fe-oxyhydroxides are smaller (ranging from 5 to $20 \mu \mathrm{m}$ ) and have an angular shape. These phases have a high Fe/As molar ratio in soil (19-99; Fig. 2b) and a variable Fe/As molar ratio in sediment (22-2727, not shown here). Moreover, of all the Fe-oxyhydroxides in the 0-5 cm sediment layer, only a few of these oxyhydroxides shows in situ Mn contents ranging from 4.4 to $13.2 \mathrm{wt} . \%$ and contain up to $1.0 \mathrm{wt} . \%$ of As. The micro-Raman identified well-crystallized goethite $(\alpha-\mathrm{FeOOH})$ with peaks at 395.5, 547.9 and $685.0 \mathrm{~cm}^{-1}$ (Fig. 7) (de Faria et al., 1997) and hematite $\left(\mathrm{Fe}_{2} \mathrm{O}_{3}\right)$ with peaks at 225.0, 282.9, 418.4 and $610.2 \mathrm{~cm}^{-1}$ (Fig. 7), plus a broad peak at $1370 \mathrm{~cm}^{-1}$ (not shown here) (de Faria et al., 1997). Poorly organized Fe hydroxides like ferrihydrite were also observed with strong peaks at 218.6 and $285.4 \mathrm{~cm}^{-1}$ (Fig. 7) (Jia et al., 2006).

Another type of Fe-oxyhydroxide (group III, Fig. 6) has higher in situ As concentrations (4.116.2 wt.\%) than Fe-oxyhydroxides of group II. It is mainly observed in the coherent weathered bedrock and the two deepest soil layers and sparsely distributed in the other upper layers. These As-rich Fe-oxyhydroxides, intermediate between arsenates (group I) and Feoxyhydroxides (group II), have a Fe/As molar ratio ranging from 2 to 9 in soil (Fig. 2b). The identification by micro-Raman spectroscopy shows that these phases are poorly organized ferrihydrite relative to the large bands centred at $\approx 650 \mathrm{~cm}^{-1}$. These ferrihydrites have higher contents of As (ranging between 4.07 and 15.4 wt.\%; Table 3) than the other types, probably related to their lower crystallinity.

The fourth identified As-bearing phases are (Si, Al)-rich phases (group IV; Fig. 6). These particles are present in various studied solid materials. Silicon and Al are the major elements (respectively from 10.3 to 20.5 wt.\% of Si and between 4.6 and 17.2 wt.\% of Al) with smaller amounts of $\mathrm{Fe}$ (ranging from 1.4 to $19.9 \mathrm{wt} . \%$ ). They are the least concentrated As-bearing phases (As concentrations up to 1.9 wt.\%) with a variable Fe/As molar ratio ranging from 6 to 134 in soil horizons and from 38 to 3024 in sediments (Fig. 2b). Their EPMA chemical composition cannot be related to a specific mineralogical composition as they may be composed of an assemblage of clays and fine grains of oxyhydroxide. During analysis the EPMA beam has a volume greater than $1-2 \mu \mathrm{m}^{3}$. Therefore, microdiffraction analyses were performed to better discriminate the mineralogy of these mineralogical assemblages. The $\mu$ XRD pattern from the composite particles shows the presence of kaolinite $(7.14,6.36$ and $3.58 \AA$ ) and muscovite $(9.94,4.49,3.49$ and $3.17 \AA$ ) (Fig. 8) and with illite, montmorillonite 
and sometimes clinochlore (not shown). The Debye images are often discontinuous and spotty due to the mixing of large grains of mica and fine-grained kaolinite (Fig. 8). The Feoxyhydroxides in these sediments, such as goethite, show a Debye cone containing continuous and homogeneous diffraction rings compared to the clay minerals, indicating crypto-crystalline nanometer-sized goethite particles.

In the present study, all the observations at the grain scale combined with XAS modelling shed light on the representativity of in situ As-bearing phases and provided quantitative information on both the proportions of As(V) and As(III) and the molecular environment of As. Thus, arsenates as Ba-rich pharmacosiderite and As-rich Fe-oxyhydroxides are the dominant As-bearing phases in the coherent weathered bedrock and the 135-165 cm soil layer. To a lesser extent, aluminosilicates are additional As carriers in the $0-5 \mathrm{~cm}$ and $135-165 \mathrm{~cm}$ soil layers. In the $0-5 \mathrm{~cm}$ and 5-20 cm sediment layers, Fe-oxyhydroxides (goethite, hematite and ferrihydrite) and aluminosilicate aggregates, corresponding to an assemblage of muscovite and kaolinite-type clays, are the predominant As-bearing phases (Table 3).

The results from in situ analysis support those from XAS fitting indicating that $\mathrm{Fe}$ is the dominant pool for As with a smaller contribution of Al. As indicated by EPMA, the (Si, Al)rich phases are however the least concentrated in As and their overall contribution is related to the relative abundance of the Al phase over the Fe one in the 5-20 cm sediment layer as well as in the soil profile (e.g. Al/Fe molar ratio in 5-20 cm sediment layer $=6-174$ in $135-$ $165 \mathrm{~cm}$ soil layer;Table 1). XAS fitting results for the 5-20 $\mathrm{cm}$ sediment layer further show that, in addition to As bound to Fe and Al phases, a small proportion of an As(III)-S species is present. The exact nature of this phase remains to be clarified. Relict primary sulfides were observed neither in the soil horizons nor sediments although they were present in the Upper Isle river sediments (Grosbois et al., 2007). Precipitation of amorphous $\mathrm{As}_{2} \mathrm{~S}_{3}$ is usually favored by reducing, acidic $(\mathrm{pH}<4)$ and S-rich conditions (Plant et al., 2003). Although these conditions might occur at a micro-scale under intense microbial activity, a more likely hypothesis for these low S sediments would be the formation of framboidal pyrite, which can act as a preferential site for As sorption (Wilkin et al., 2003). Kwong et al. (2007) observed framboidal pyrites in surface sediments from a neutral drainage wetland and explained their presence by the reducing conditions in local microsites favouring $\mathrm{SO}_{4}$ reduction. Additional micro-scale characterization would be necessary to assess this possibility and/or to rule out the presence of relict primary sulfides.

\subsection{Fate of solid arsenic in the different reservoirs}

The Ba-rich pharmacosiderite occurred in various alteration states in the weathered bedrock and the deepest soil layer but did not persist in the soil profile towards the surface. Indeed, the in situ mineralogical characterization showed an evolution of As-bearing phases through the soil profile: Fe-oxyhydroxides became the major sink of As with a large range of in situ concentrations, with less and less As towards the upper soil layers and increasing Fe/As molar ratios. Such progressive decay of the pharmacosiderite component and sorption of As on Feoxyhydroxides towards the soil surface was observed by Morin et al. (2002) in a previous study over another As-geochemical anomaly. This As loss may be related to As-bearing phase ageing during pedogenesis ([Krause and Ettel, 1989], [Sadiq, 1997], [Morin et al., 2002], [Paktunc et al., 2004] and [Morin and Calas, 2006]). It is likely that arsenates were transformed into ferrihydrite, goethite and hematite during pedogenesis as has been previously observed ([Alpers et al., 1994], [Bigham et al., 1996] and [Courtin-Nomade et al., 2003]). In addition, several studies have reported that the solubility of these As-rich Fe- 
oxyhydroxides usually decreases with increasing Fe/As ratios ([Harris and Monette, 1989], [Krause and Ettel, 1989], [Paktunc et al., 2003], [Paktunc et al., 2008] and [Cancès et al., 2008]). However, the overall mobility of As will also depend on other soil parameters reflecting the ongoing pedogenetic processes specific to a given soil horizon (e.g. pH, organic matter and clay contents, microbial activity, interstitial water volumes) and so, pedogenetic processes can be considered as key factors influencing the stability of secondary minerals.

No significant evolution of the As -bearing phases was observed in sediments from deeper to water-sediment interface. However, Fe-oxyhydroxides contained less As (0.04-0.87 wt.\%) in the 5-20 cm sediment layer than in the 0-5 cm layer (up to $2.25 \mathrm{wt} . \%$ ) which was correlated with bulk As concentrations (455-1649 $\mathrm{mg} \mathrm{kg}^{-1}$ in the 5-20 $\mathrm{cm}$ and $0-5 \mathrm{~cm}$ sediment layers, respectively).

\section{Conclusions}

This study shows the importance of As-bearing phases like arsenates (Ba-rich pharmacosiderite) and Fe-oxyhydroxides (goethite, hematite and ferrihydrite) in As retention in soil and sediments located in an As-geochemical anomaly. The present study thus yields another example of the evolution from Ba-rich pharmacosiderite to As-bearing Feoxyhydroxides upon soil formation, a previous one being found and reported by Morin et al. (2002) on another geochemical As anomaly in the French Massif Central.

Although bulk As concentrations are in the same range in soil and sediment, the identified Asbearing phases are different. This is probably linked to erosion and pedogenetic processes that change the solid speciation of As. Indeed, the studied subwatershed drains As-rich granite and metamorphic rocks containing sulfides (arsenopyrite and As-rich pyrite) as primary As carriers. The alteration of arsenopyrite gives secondary phases such as pharmacosiderite found in the coherent weathered bedrock (granite) and the deepest soil layer. A mineralogical evolution seems to take place with Fe-oxyhydroxides (ferrihydrite, goethite and hematite), containing less and less As towards the upper soil layer and in sediments. These transformations imply that the solubility of all the As-bearing phases is different. Iron phases are likely to be less stable in sediments than in soil during weathering and transport mechanisms due to seasonal redox conditions.

Arsenic mobility from the solid fraction to surface waters depends on the solid phase stability. In order to estimate the lability of these different As-bearing phases, a related study dealing with chemical extractions and column leaching tests on the soil and sediments is ongoing (Bossy et al., work in progress).

\section{Acknowledgements}

This research was supported by the « Conseil régional du Limousin » (France), GRESE Laboratory (France), BRGM (France), Natural Resources Canada, (CANMET-MMSL, Canada) and University of McGill (Canada). The authors would like to thank C. Dere (University of Limoges, France) for her help during the soil sampling campaign, H. Lalande (McGill University, Canada) for ICP-MS analyses on soil and sediments, C. Crouzet (BRGM, France) for ICP-MS analyses on suspended matter and T. MacKinnon (CANMET, Canada) for sample preparation at the synchrotron and synthesis of standards. Special thanks are extended to Dr. D. Paktunc (Natural Resources Canada, Ottawa) who generously shared XAS data for pharmacosiderite. The authors would like also to thank the Associate Editor, Dr. K. 
Savage, and Dr. G. Morin (University of Paris, France) and an anonymous reviewer for thorough reviews of on an earlier version of the manuscript. The National Synchrotron Light Source is supported by the US Department of Energy, Division of Material Sciences and Division of Chemical Sciences, under contract number DE-AC02-98CH10886. The beamline X11 is supported by the Office of Naval Research and contributions from Participating Research Team (PRT) members. The Advanced Light Source is supported by the US Department of Energy, Office of Science and Office of Basic Energy Sciences under contract number DE-AC02-05CH11231.

\section{References}

Ali and Dzombak, 1996 A.M. Ali and D.A. Dzombak, Interactions of copper, organic acids, and sulfate in goethite suspensions, Geochim. Cosmochim. Acta 60 (1996), pp. 5045-5053.

Alpers et al., 1994 C.N. Alpers, D.W. Blowes, D.K. Nordstrom and J.L. Jambor, Secondary minerals and acid-mine water chemistry. In: J.L. Jambor and D.W. Blowes, Editors, Environmental Geochemistry of Sulfides Mine-Wastes vol. 22, Mineral. Assoc. Canada, Waterloo, Ontario (1994), pp. 248-270.

Baize, 1997 Baize, D., 1997. Teneurs totales en éléments traces métalliques dans les sols (France). éd. INRA, Versailles.

Baur and Onishi, 1969 W.H. Baur and B.M.H. Onishi, Arsenic. In: K.H. Wedepohl, Editor, Handbook of Geochemistry, Springer-Verlag, Berlin (1969).

Beauchemin and Kwong, 2006 S. Beauchemin and Y.T.J. Kwong, Impact of redox conditions on arsenic mobilization from tailings in a wetland with neutral drainage, Environ. Sci.

Technol. 40 (2006), pp. 6297-6303.

Beauchemin et al., 2002 S. Beauchemin, D. Hesterberg and M. Beauchemin, Principal component analysis approach for modeling sulfur K-XANES spectra of humic acids, Soil Sci. Soc. Am. J. 66 (2002), pp. 83-91.

Bigham et al., 1996 J.M. Bigham, U. Schwertmann, S. Traina, R.L. Winland and M. Wolf, Schwertmannite and the chemical modelling of iron in acid sulphate waters, Geochim. Cosmochim. Acta 60 (1996), pp. 2111-2121.

Bouchot et al., 1989 V. Bouchot, Y. Gros and M. Bonnemaison, Structural controls on the auriferous shear zones of the Saint-Yrieix district, Massif Central, France. Evidence from the Le Bourneix and Lauriéras gold deposits, Econ. Geol. 84 (1989), pp. 1315-1327.

Bouchot et al., 2005 V. Bouchot, P. Ledru, C. Lerouge, J.L. Lescuyer and J.P. Milesi, Late Variscan mineralizing systems related to orogenic processes: the French Massif Central, Ore Geol. Rev. 27 (2005), pp. 169-197.

Boyle and Jonasson, 1973 R.W. Boyle and I.R. Jonasson, The geochemistry of As and its use as an indicator element in geochemical prospecting, J. Geochem. Explor. 2 (1973), pp. 251296. 
Burnol et al., 2007 A. Burnol, F. Garrido, P. Baranger, C. Joulian, M.C. Dictor, F. Bodénan, G. Morin and L. Charlet, Decoupling of arsenic and iron release from ferrihydrite suspension under reducing conditions: a biogeochemical model, Geochem. Trans. (2007)

Cancès et al., 2008 B. Cancès, F. Juillot, G. Morin, V. Laperche, D. Polya, D.J. Vaughan, J.L. Hazemann, O. Proux, G.E. Brown and G. Calas, Changes in arsenic speciation through a contaminated soil profile: a XAS based study, Sci. Total Environ. 397 (2008), pp. 178-189.

Casiot et al., 2009 C. Casiot, M. Egal, F. Elbaz-Poulichet, O. Bruneel, C. Bancon-Montigny, M.A. Cordier, E. Gomez and C. Aliaume, Hydrological and geochemical control of metals and arsenic in a Mediterranean river contaminated by acid mine drainage (the Amous River, France); preliminary assessment of impacts on fish (Leuciscus cephalus), Appl. Geochem. 24 (2009), pp. 787-799.

Cauuet, 1999 B. Cauuet, L'or dans l'antiquité de la mine à l'objet, Aquitania 9 (1999).

Chéry and Gateau, 1998 Chéry, L., Gateau, C., 1998. Mise à disposition de l'inventaire géochimique sur le territoire national (pour identifier les zones à risques de teneurs naturelles élevées en métaux lourds dans les eaux destinées à l'AEP). Rapport BRGM R40207.

Courtin-Nomade et al., 2003 A. Courtin-Nomade, H. Bril, C. Neel and J.F. Lenain, Arsenic in iron cements developed within tailings of a former metalliferous mine - Enguialès, Aveyron, France Appl. Geochem. 18 (2003), pp. 395-408.

Courtin-Nomade et al., 2005 A. Courtin-Nomade, C. Grosbois, H. Bril and C. Roussel, Spatial variability of arsenic in some iron-rich deposits generated by acid mine drainage, Appl. Geochem. 20 (2005), pp. 383-396.

Craw et al., 2003 D. Craw, D. Falconer and J.H. Yougson, Environmental arsenopyrite stability and dissolution: theory, experiment and field observations, Chem. Geol. 199 (2003), pp. 71-82.

de Faria et al., 1997 D.L.A. de Faria, S. Venâncio Silva and M.T. de Oliveira, Raman microspectroscopy of some iron oxides and oxyhydroxides, J. Raman Spectrosc. 28 (1997), pp. 873-878.

De Vitre et al., 1991 R. De Vitre, N. Belzile and A. Tessier, Speciation and adsorption of arsenic on diagenetic iron oxyhydroxides, Limnol. Oceanogr. 36 (1991), pp. 1480-1485

Dove and Rimstidt, 1985 P.M. Dove and J.D. Rimstidt, The solubility and stability of scorodite, $\mathrm{FeAsO}_{4} \cdot 2 \mathrm{H}_{2} \mathrm{O}$, Am. Mineral 70 (1985), pp. 838-844.

Drahota et al., 2009 P. Drahota, J. Rohovec, M. Filippi, M. Mihaljevič, P. Rychlovský, V. Červený and Z. Pertold, Mineralogical and geochemical controls of arsenic speciation and mobility under different redox conditions in soil, sediment and water at the Mokrsko-West gold deposit, Czech Republic, Sci. Total Environ. 407 (2009), pp. 3372-3384.

Duchaufour, 1991 P. Duchaufour, Pédologie: sol, végétation, environnement (third ed.), Masson, Paris (1991). 
Fergusson, 1990 J.E. Fergusson, The Heavy Elements: Chemistry, Environmental Impact and Health Effects, Pergamon Press, Oxford (1990).

Filippi et al., 2007 M. Filippi, B. Doušová and V. Machovič, Mineralogical speciation of arsenic in soils above the Mokrsko-west gold deposit, Czech Republic, Geoderma 139 (2007), pp. $154-170$.

Floc'h, 1983 Floc'h, J.P., 1983. La série métamorphique du Limousin central: une traverse de la branche ligérienne de l'orogénèse varisque, de l'Aquitaine à la zone broyée d'Argentat (Massif Central Français). HDR Thesis, Univ. of Limoges.

Foley et al., 1978 R. Foley, J.R. Spotila, J.P. Giesy and H. Wall, Arsenic concentrations in water and fish from Chautauqua Lake, New York, Environ. Biol. Fish 3 (1978), pp. 361-367.

Frost and Kloprogge, 2003 R.L. Frost and J.T. Kloprogge, Raman spectroscopic of some complex arsenate minerals-implication for soils remediation, Spectrochim. Acta A 59 (2003), pp. 2797-2804.

Frost et al., 2009 R.L. Frost, J. Sejkora, S. Cejka and E.C. Keeffe, Raman spectroscopic study of the mixed anion sulphate-arsenate mineral parnauite $\mathrm{Cu}_{9}\left[(\mathrm{OH})_{10}\left|\mathrm{SO}_{4}\right|\left(\mathrm{AsO}_{4}\right)_{2}\right] \cdot 7 \mathrm{H}_{2} \mathrm{O}, J$.

Raman Spectrosc. (2009)

Goldberg, 2002 S. Goldberg, Competitive adsorption of arsenate and arsenite on oxides and clay minerals, Soil Sci. Soc. Am. J. 66 (2002), pp. 413-421.

Grosbois et al., 2007 C. Grosbois, A. Courtin-Nomade, F. Martin and H. Bril, Transportation and evolution of trace element bearing phases in stream sediments in a mining-influenced basin (Upper Isle River, France), Appl. Geochem. 22 (2007), pp. 2362-2374.

Grosbois et al., 2009 C. Grosbois, J. Schäfer, H. Bril, G. Blanc and A. Bossy, Deconvolution of trace element (As, Cr, Mo, Th, U) sources and pathways to surface waters of a gold mining-influenced watershed, Sci. Total Environ. 407 (2009), pp. 2063-2076.

Harris and Monette, 1989 Harris, G.B., Monette, S., 1989. The disposal of arsenical residues. In: Proc. Productivity and Technology in the Metallurgical Industries, Cologne, West Germany.

Hess and Blanchar, 1976 R.E. Hess and R.W. Blanchar, Arsenic stability in contaminated soils, Soil Sci. Soc. Am. J. 40 (1976), pp. 847-852.

Hill et al., 2000 I.G. Hill, R.H. Worden and I.G. Meighan, Geochemical evolution of a palacolaterite: the interbasaltic formation, Northern Ireland, Chem. Geol. 166 (2000), pp. 6584.

Hoins et al., 1993 U. Hoins, L. Charlet and H. Sticher, Ligand effect on the adsorption of heavy metals: the sulfate-cadmium-goethite case, Water Air Soil Pollut. 68 (1993), pp. 241255.

Horowitz, 1991 A.J. Horowitz, A Primer on Sediment-Trace Element Chemistry (second ed.), Lewis Publishers (1991). 
Jia et al., 2006 Y. Jia, L. Xu, Z. Fang and G.P. Demopoulos, Observation of surface precipitation of arsenate on ferrihydrite, Environ. Sci. Technol. 40 (2006), pp. 3248-3253.

Jones et al., 1997 C.A. Jones, W.P. Inskeep and D.R. Neuman, Arsenic transport in contaminated mine tailings following liming, J. Environ. Qual. 26 (1997), pp. 433-439.

Krause and Ettel, 1989 E. Krause and V.A. Ettel, Solubilities and stabilities of ferric arsenate compounds, Hydrometallurgy 22 (1989), pp. 311-337.

Kunz et al., 2009 M. Kunz, N. Tamura, K. Kai Chen, A.A. MacDowell, R.S. Celestre, M.M. Church, S. Fakra, E.E. Domning, J.M. Glossinger, J.L. Kirschman, G.Y. Morrison, D.W.

Plate, B.V. Smith, T. Warwick, V.V. Yashchuk, H.A. Padmore and E. Ustundag, A dedicated superbend X-ray microdiffraction beamline for materials, geo-, and environmental sciences at the advanced light source, Rev. Sci. Instrum. 80 (2009), p. 035108.

Kurtz et al., 2000 A. Kurtz, L.A. Derry, O.A. Chadwick and M.J. Alfano, Refractory element mobility in volcanic soils, Geology 28 (2000), pp. 683-686.

Kwong et al., 2007 Y.T.J. Kwong, S. Beauchemin, M.F. Hossain and W.D. Gould, Transformation and mobilization of arsenic in the historic Cobalt mining camp, Ontario, Canada, J. Geochem. Explor. 92 (2007), pp. 133-150.

Lin and Puls, 2000 Z. Lin and R.W. Puls, Adsorption, desorption and oxidation of arsenic affected by clay minerals and aging process, Environ. Geol. 39 (2000), pp. 753-759

Lin and Puls, 2003 Z. Lin and R.W. Puls, Potential indicators for the assessment of arsenic natural attenuation in the subsurface, Environ. Res. 7 (2003), pp. 825-834.

Manning and Goldberg, 1997 B.A. Manning and S. Goldberg, Arsenic (III) and arsenic (V) adsorption on three California soils, Soil Sci. 162 (1997), pp. 886-895.

Mok and Wai, 1990 W. Mok and C.M. Wai, Distribution and mobilization of arsenic and antimony species in the Cœur D'Alene River, Idaho, Environ. Sci. Technol. 24 (1990), pp. $102-108$.

Moore and Luoma, 1990 J.N. Moore and S.N. Luoma, Hazardous wastes from large-scale metal extraction, Environ. Sci. Technol. 24 (1990), pp. 1278-1285.

Morin and Calas, 2006 G. Morin and G. Calas, Arsenic in soils, mine tailings, and former industrial sites, Elements 2 (2006), pp. 97-101

Morin et al., 2002 G. Morin, D. Lecocq, F. Juillot, G. Calas, P. Ildefonse, S. Belin, V. Briois, P. Dillmann, P. Chevallier, C. Gauthier, A. Sole, P.E. Petit and S. Borensztajn, EXAFS evidence of sorbed arsenic(V) and pharmacosiderite in a soil overlying the Echassières geochemical anomaly, Allier, France, Bull. Soc. Géol. France 173 (2002), pp. 281-291

Mutter et al., 1984 G. Mutter, W. Eysel, O. Greis and K. Schmetzer, Crystal chemistry of natural and ion-exchanged pharmacosiderites, Neues Jb. Miner. Monat. 4 (1984), pp. 183-192.

NF ISO 10390, 1994 NF ISO 10390, 1994. Qualité du sol. Détermination du pH. AFNOR. 
NF ISO 10694, 1995 NF ISO 10694, 1995. Qualité du sol. Dosage du carbone organique et du carbone total après combustion sèche (analyse élémentaire). AFNOR.

NF ISO 14869-2, 2002 NF ISO 14869-2, 2002. Qualité du Sol. Mise en solution pour la détermination des teneurs élémentaires totales. Partie 2: Mise en solution par fusion alcaline. AFNOR.

Nicaud, 2001 Nicaud, J., 2001. Contrôle structural de la mise en place des minéralisations aurifères du District de Saint-Yrieix-la-Perche (Massif Central français): analyse de la fracturation et étude des altérations hydrothermales. PhD Thesis, Univ. Limoges.

Nriagu, 1994 J.O. Nriagu, Arsenic in the environment. Part I: cycling and characterization, Adv. Environ. Sci. Technol. 26 (1994) (Willey).

O’Day, 2006 P.A. O’Day, Chemistry and mineralogy of arsenic, Elements 2 (2006), pp. 7783.

Orsini et al., 1994 Orsini, A., Mori, C., Migon, C., Gibert, J., 1994. Impact d'un enrichissement en arsenic et en antimoine sur les invertébrés benthiques et les poissons d'un cours d'eau de Corse. Proc. 4th Int. Conf. Limnologues d'Expression Française, Marrakech, vol. 22, pp. 200-235.

Paktunc et al., 2003 D. Paktunc, A. Foster and G. Laflamme, Speciation and characterization of arsenic in Ketza River mine tailings using X-ray absorption spectroscopy, Environ. Sci. Technol. 37 (2003), pp. 2067-2074

Paktunc et al., 2004 D. Paktunc, A. Foster, S. Heald and G. Laflamme, Speciation and characterization of arsenic in gold ores and cyanidation tailings using X-ray absorption spectroscopy, Geochim. Cosmochim. Acta 68 (2004), pp. 969-983.

Paktunc et al., 2008 D. Paktunc, J. Dutrizac and V. Gertsman, Synthesis and phase transformations involving scorodite, ferric arsenate and arsenical ferrihydrite: implications for arsenic mobility, Geochim. Cosmochim. Acta 72 (2008), pp. 2649-2672.

Plant et al., 2003 Plant, J.A., Kinniburgh, D.G., Smedley, P.L., Fordyce, F.M., Klinck, B.A., 2003. Arsenic and selenium. In: Lollar, B.S. (Ed.), Environmental Geochemistry. Holland, H.D., Turekian, K.K. (Exec. Eds), Treatise on Geochemistry, vol. 9. Elsevier, pp. 17-66.

Rahn and McCafrey, 1979 K.A. Rahn and R.J. McCafrey, Compositional differences between Arctic aerosol and snow, Nature 280 (1979), pp. 479-480.

Ravel and Newville, 2005 B. Ravel and M. Newville, ATHENA, ARTEMIS, HEPHAESTUS: data analysis for X-ray absorption spectroscopy using IFEFFIT, $J$. Synchrotron Rad. 12 (2005), pp. 537-541.

Reimann et al., 2000 C. Reimann, D. Banks and P. De Caritat, Impacts of airborne contamination on regional soil and water quality: the Kola Peninsula, Russia, Environ. Sci. Technol. 34 (2000), pp. 2727-2732. 
Rochette et al., 1998 E.A. Rochette, G.C. Li and S.E. Fendorf, Stability of arsenate minerals in soil under biotically generated reducing conditions, Soil Sci. Soc. Am. J. 62 (1998), pp. $1530-1537$.

Roussel et al., 1999 C. Roussel, H. Bril and A. Fernandez, Evolution of sulphide-rich mine tailings and immobilization of As and Fe, C.R. Acad. Sci. Paris Earth Planet Sci. 329 (1999), pp. 787-794.

Roussel et al., 2000 C. Roussel, C. Neel and H. Bril, Minerals controlling arsenic and lead solubility in an abandoned gold mine tailings, Sci. Total Environ. 263 (2000), pp. 209-219.

Sadiq, 1997 M. Sadiq, Arsenic chemistry in soils: an overview of thermodynamic predictions and field observations, Water Air Soil Pollut. 93 (1997), pp. 117-136.

Schwertmann and Cornell, 1991 U. Schwertmann and R.M. Cornell, Iron Oxides in the Laboratory, VCH Publ., Weinheim, Germany (1991).

Smedley and Kinniburgh, 2002 P.L. Smedley and D.G. Kinniburgh, A review of the source, behaviour and distribution of arsenic in natural waters, Appl. Geochem. 17 (2002), pp. $517-$ 568 .

Soubrand-Colin et al., 2005 M. Soubrand-Colin, H. Bril, C. Neel, A. Courtin-Nomade and F. Martin, Weathering of basaltic rocks from the French Massif Central: origin and fate of $\mathrm{Ni}, \mathrm{Cr}$, $\mathrm{Zn}$ and $\mathrm{Cu}$, Can. Mineral. 43 (2005), pp. 1103-1118.

Sullivan and Aller, 1996 K.A. Sullivan and R.C. Aller, Diagenetic cycling of arsenic in Amazon shelf sediments, Geochim. Cosmochim. Acta 60 (1996), pp. 1465-1477.

Thomas and Meybeck, 1992 R.L. Thomas and M. Meybeck, The use of particulate matter. In: D. Chapman, Editor, Water Quality Assessment, Chapman and Hall (1992), pp. 317-369.

Vicente-Martorell et al., 2009 J.J. Vicente-Martorell, M.D. Galindo-Riaño, M. García-Vargas and M.D. Granado-Castro, Bioavailability of heavy metals monitoring water, sediments and fish species from a polluted estuary, J. Hazard. Mater. 162 (2009), pp. 823-836

WHO, 2001 World Health Organization, 2001. Environmental Health Criteria 224. Arsenic and Arsenic Compounds. Geneva.

Wilkin et al., 2003 R.T. Wilkin, D. Wallschläger and R.G. Ford, Speciation of arsenic in sulfidic waters, Geochem. Trans. 4 (2003), pp. 1-7 
Figures and Tables

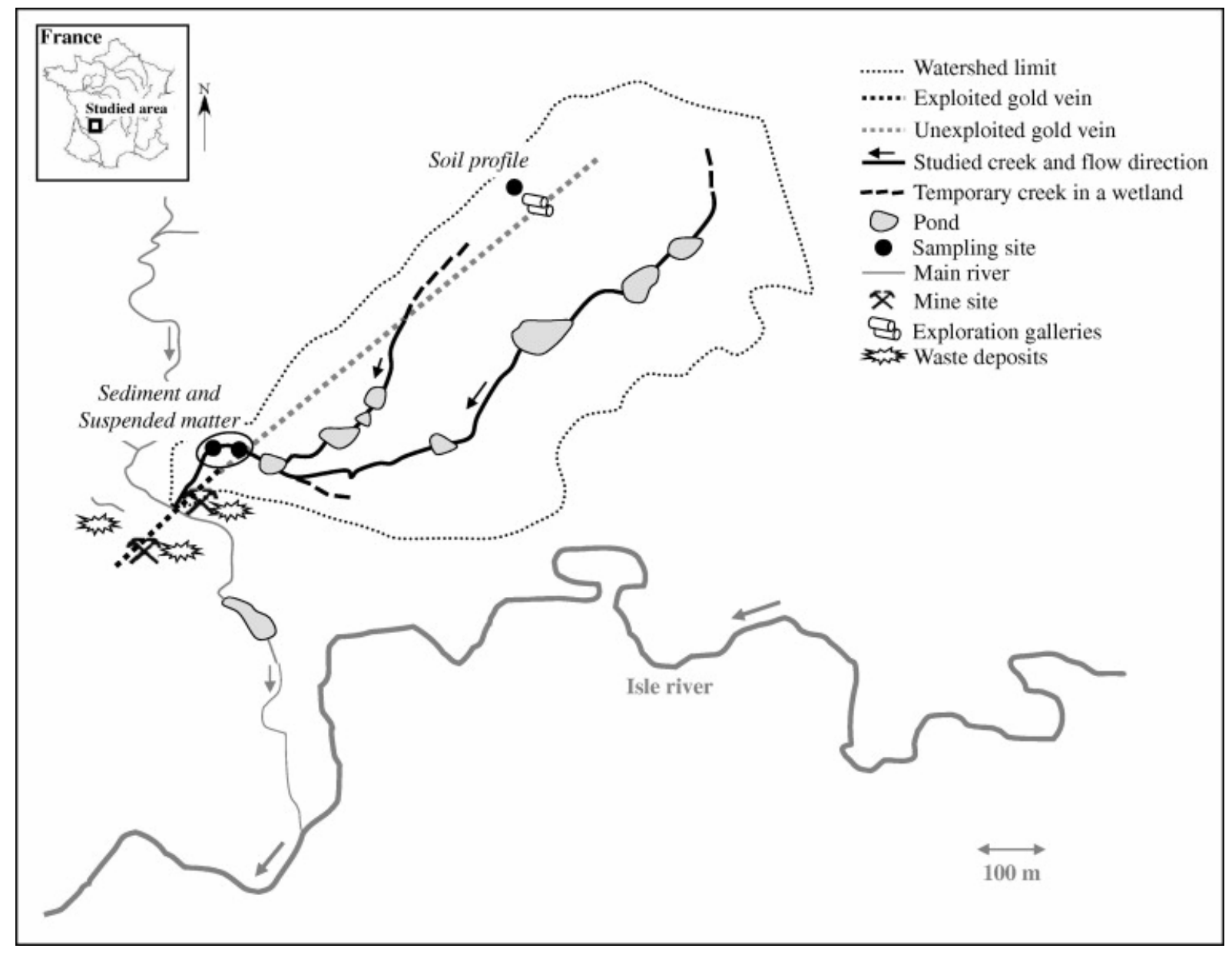

Fig. 1. Location of the studied subwatershed and sampling sites in the Saint-Yrieix-la-Perche Au mining district. 
a

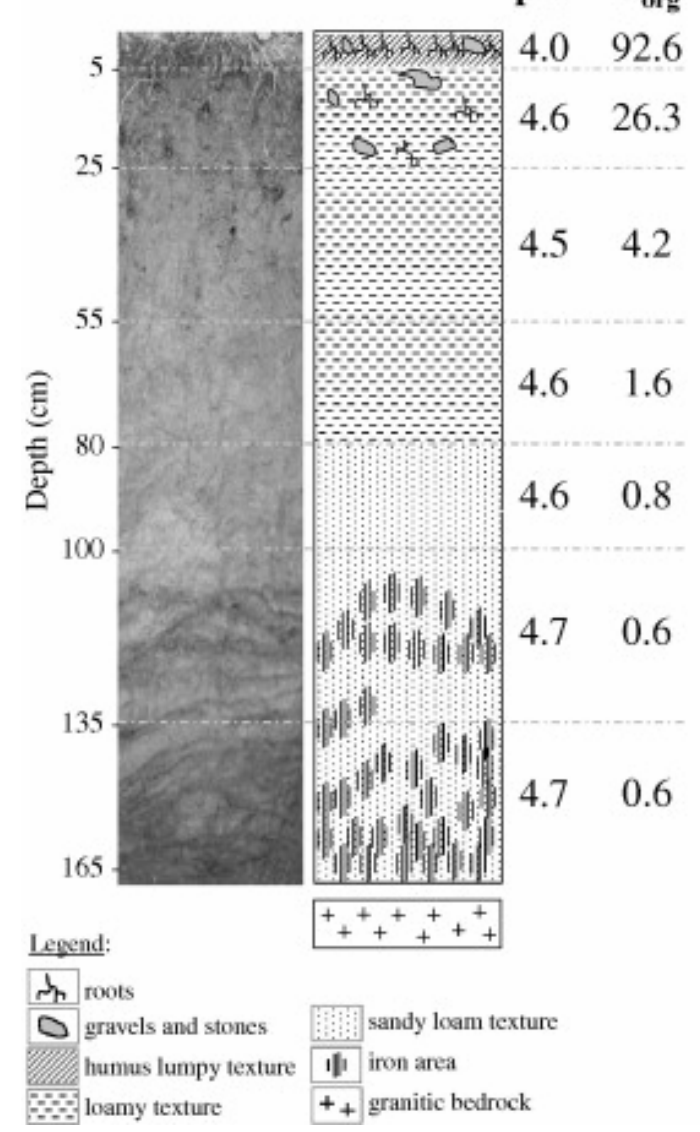

b

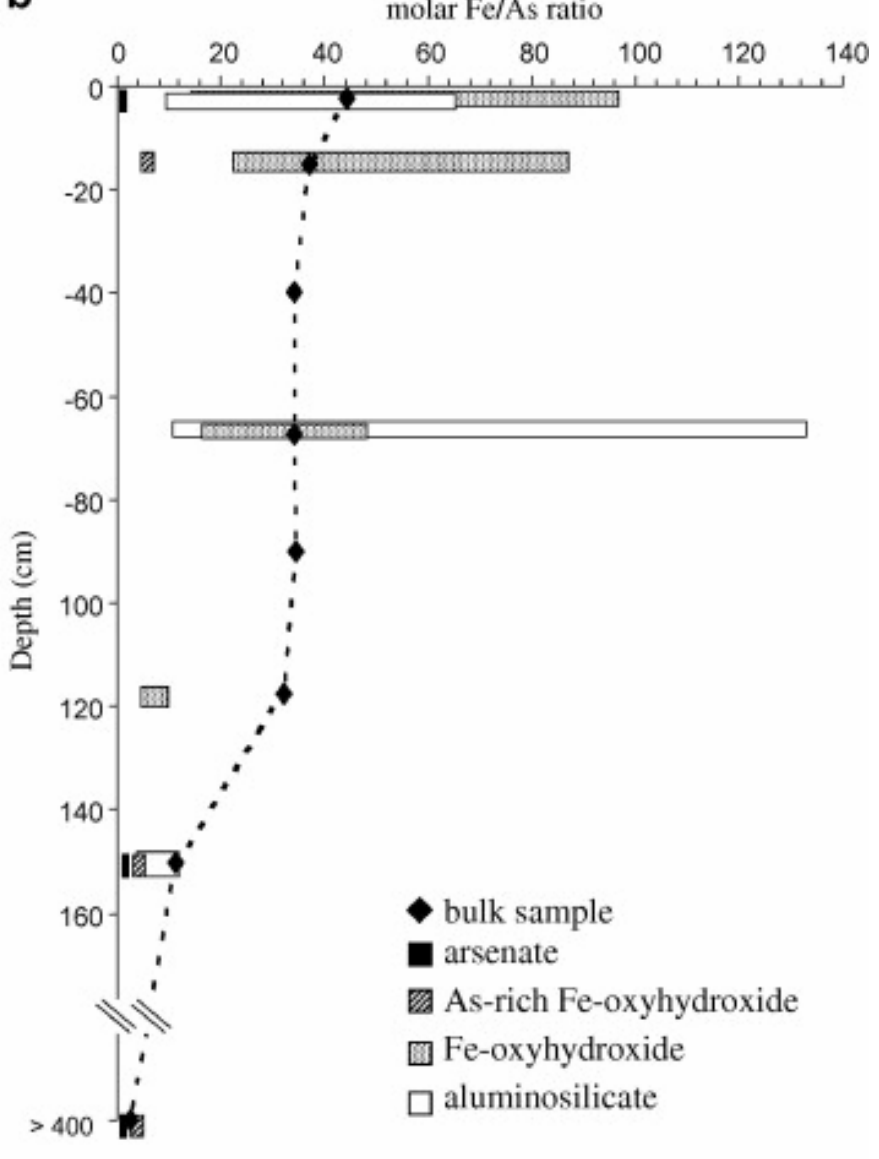

Fig. 2. (a) Soil profile photography with horizon depth and conventional diagram according to Duchaufour (1991) with $\mathrm{pH}_{\text {water }}$ and organic $\mathrm{C}$ content (expressed in $\mathrm{g} \mathrm{kg}^{-1}$ ) and (b) distribution of Fe/As molar ratios in bulk soil profile (dashed line) and in in situ bearing phases (boxes). 


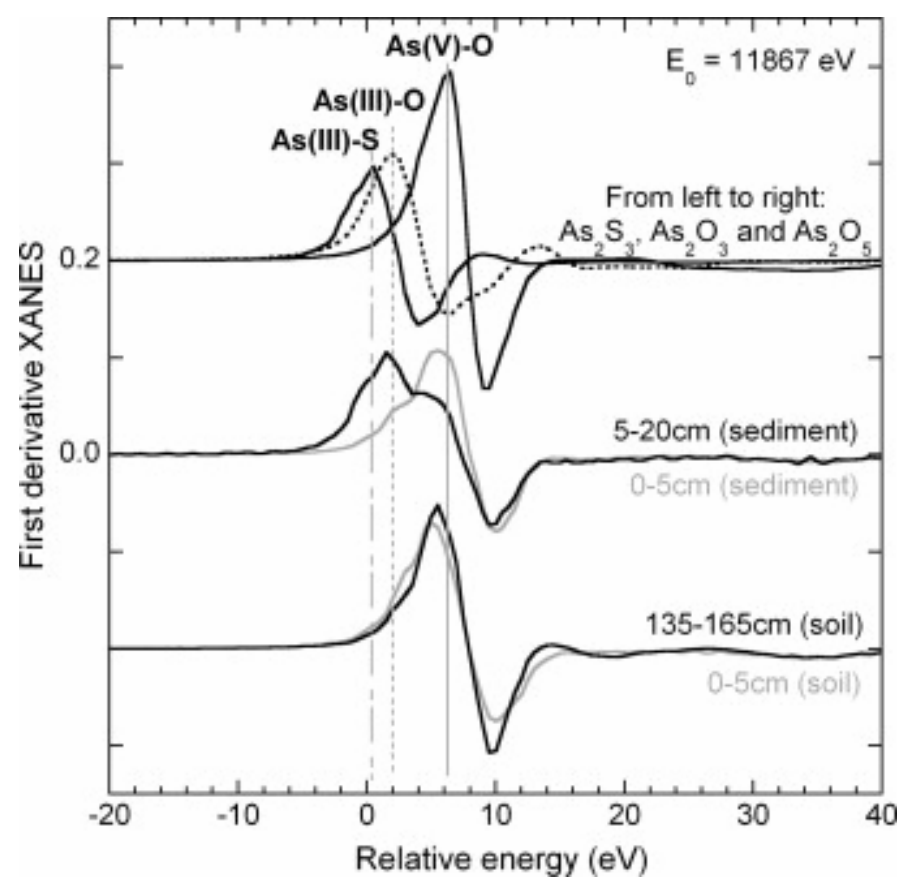

Fig. 3. First derivative As K-edge XANES spectra for the sediment and soil samples compared to reference As compounds of $\mathrm{As}_{2} \mathrm{~S}_{3}, \mathrm{As}_{2} \mathrm{O}_{3}$ and $\mathrm{As}_{2} \mathrm{O}_{5}$ as representative species of $\mathrm{As}(\mathrm{III})-\mathrm{S}, \mathrm{As}(\mathrm{III})-\mathrm{O}$ and $\mathrm{As}(\mathrm{V})-\mathrm{O}$ respectively. 

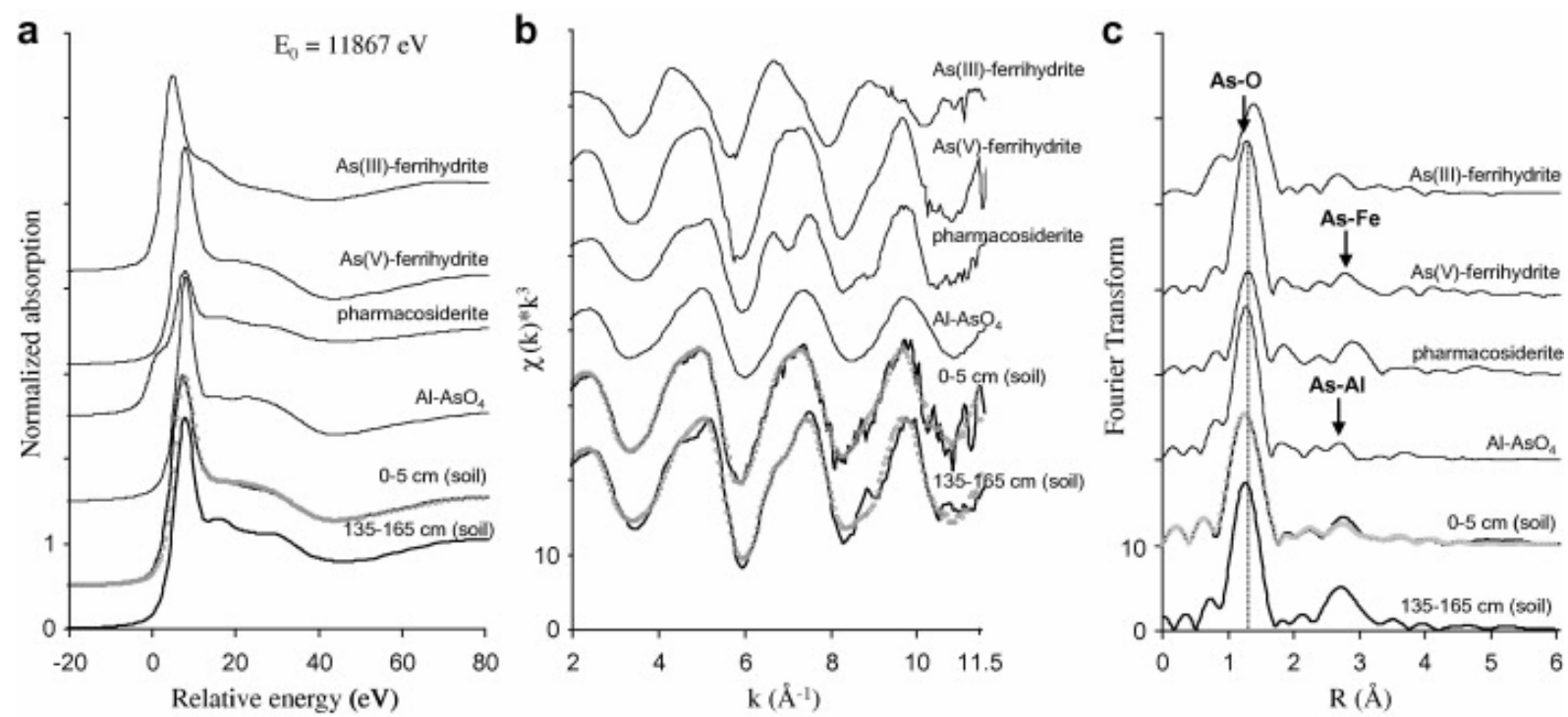

d

\begin{tabular}{|c|c|c|c|c|c|c|c|}
\hline sample & spectra & $\begin{array}{l}\text { reference compounds } \\
\text { As(III)-ferrihydrite }\end{array}$ & $\begin{array}{l}\text { (\% of total As } \pm \text { stan } \\
\text { As(V)-ferrihydrite }\end{array}$ & $\begin{array}{l}\text { lard error })^{2} \\
\text { pharmacosiderite }^{d}\end{array}$ & $\mathrm{Al}-\mathrm{AsO}_{4}{ }^{\mathrm{e}}$ & red. $\chi^{2}$ & $\sum$ fractions ${ }^{f}$ \\
\hline \multirow{2}{*}{$0-5 \mathrm{~cm}$ soil layer } & XANES & - & $87 \pm 3$ & - & $13 \pm 0$ & 0.102 & 1.011 \\
\hline & $\chi(\mathrm{k})^{8} \mathrm{k}^{3}$ & $15 \pm 6$ & $50 \pm 9$ & - & $35 \pm 0$ & 284 & 1.135 \\
\hline \multirow{2}{*}{$135-165 \mathrm{~cm}$ soil layer } & XANES & - & - & - & - & - & - \\
\hline & $\chi(\mathrm{k})^{6} \mathrm{k}^{3}$ & - & $=$ & $48 \pm 0$ & $52 \pm 4$ & 248 & 1.249 \\
\hline
\end{tabular}

Fig. 4. Measured (black line) and predicted (grey circles) As K-edge XANES (a), EXAFS $\chi(k)^{*} k^{3}$ (b) and Fourier transform (c) spectra for 0-5 cm and 135-165 cm soil layers compared with those of reference As compounds, along with linear combination fitting results (d) of As standards showing the best fit of spectra for the soil samples. 

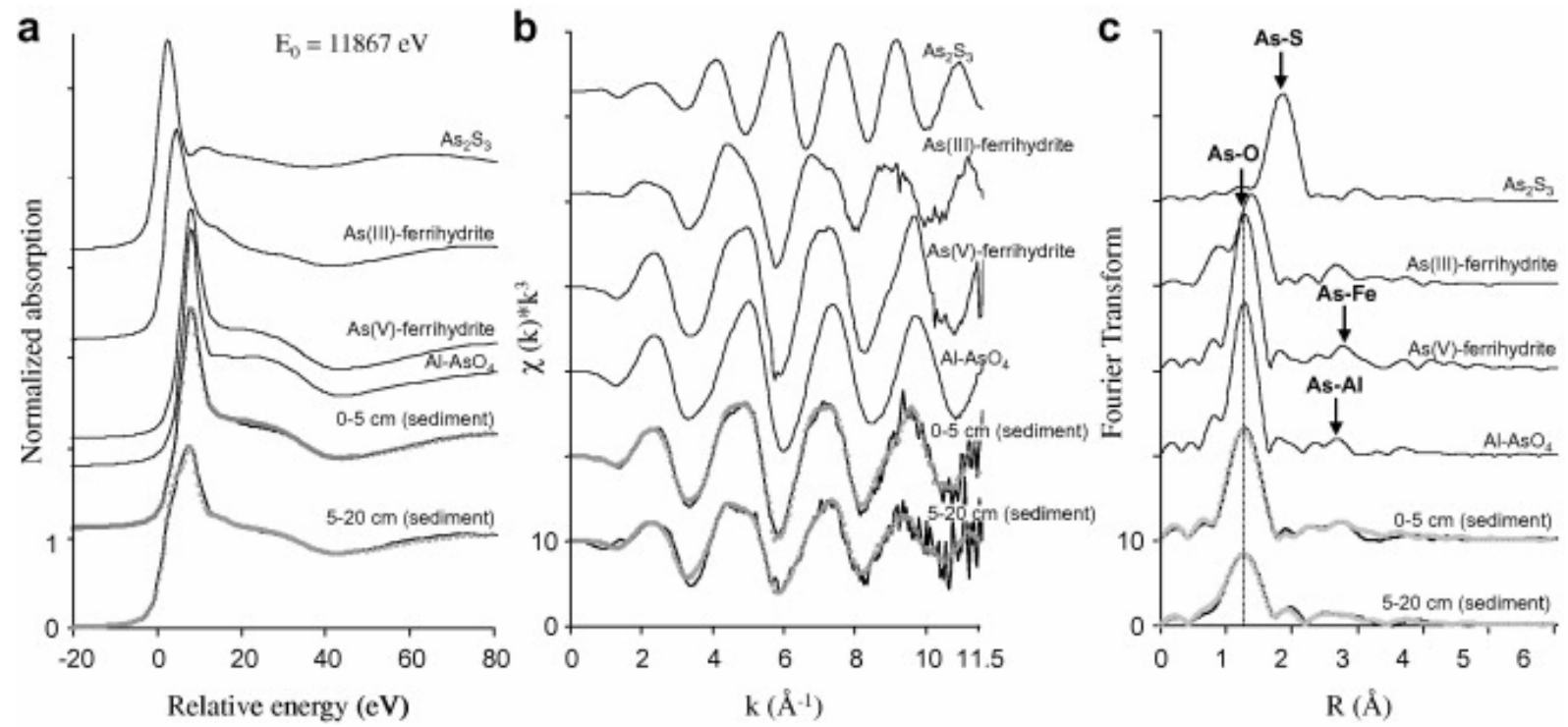

d

\begin{tabular}{|c|c|c|c|c|c|c|c|}
\hline \multirow{2}{*}{ sample } & \multirow{2}{*}{ spectra } & \multicolumn{6}{|c|}{ reference com pounds ( $\mathcal{C}$ of total As \pm standard error $)^{a}$} \\
\hline & & $\mathrm{As}_{2} \mathrm{~S}_{3}{ }^{\mathrm{b}}$ & As(III)-ferrihydrite ${ }^{c}$ & As(V)-ferrihydrite ${ }^{d}$ & $\mathrm{Al}-\mathrm{AsO}_{4}{ }^{\mathrm{C}}$ & red. $\chi^{2}$ & $\Sigma$ fractions ${ }^{\prime}$ \\
\hline \multirow{2}{*}{$0-5 \mathrm{~cm}$ sediment layer } & XANES & - & $13 \pm 0$ & $87 \pm 1$ & 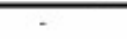 & 0.069 & 1.002 \\
\hline & $\chi(\mathrm{k})^{*} \mathrm{k}^{3}$ & - & $31 \pm 3$ & $56 \pm 5$ & $13 \pm 0$ & 179 & 1.005 \\
\hline \multirow{2}{*}{$5-20 \mathrm{~cm}$ sediment layer } & XANES & $11 \pm 1$ & $48 \pm 1$ & - & $41 \pm 1$ & 0.114 & 1.022 \\
\hline & $\chi(\mathrm{k})^{*} \mathrm{k}^{3}$ & $15 \pm 2$ & $51 \pm 3$ & - & $34 \pm 2$ & 340 & 0.997 \\
\hline
\end{tabular}

Fig. 5. Measured (black line) and predicted (grey circles) As K-edge XANES (a), EXAFS $\chi(k)^{*} k^{3}$ (b) and Fourier transform (c) spectra for 0-5 cm and 5-20 cm sediment layers compared with those of reference As compounds, along with linear combination fitting results (d) of As standards showing the best fit of spectra for the sediment samples. 


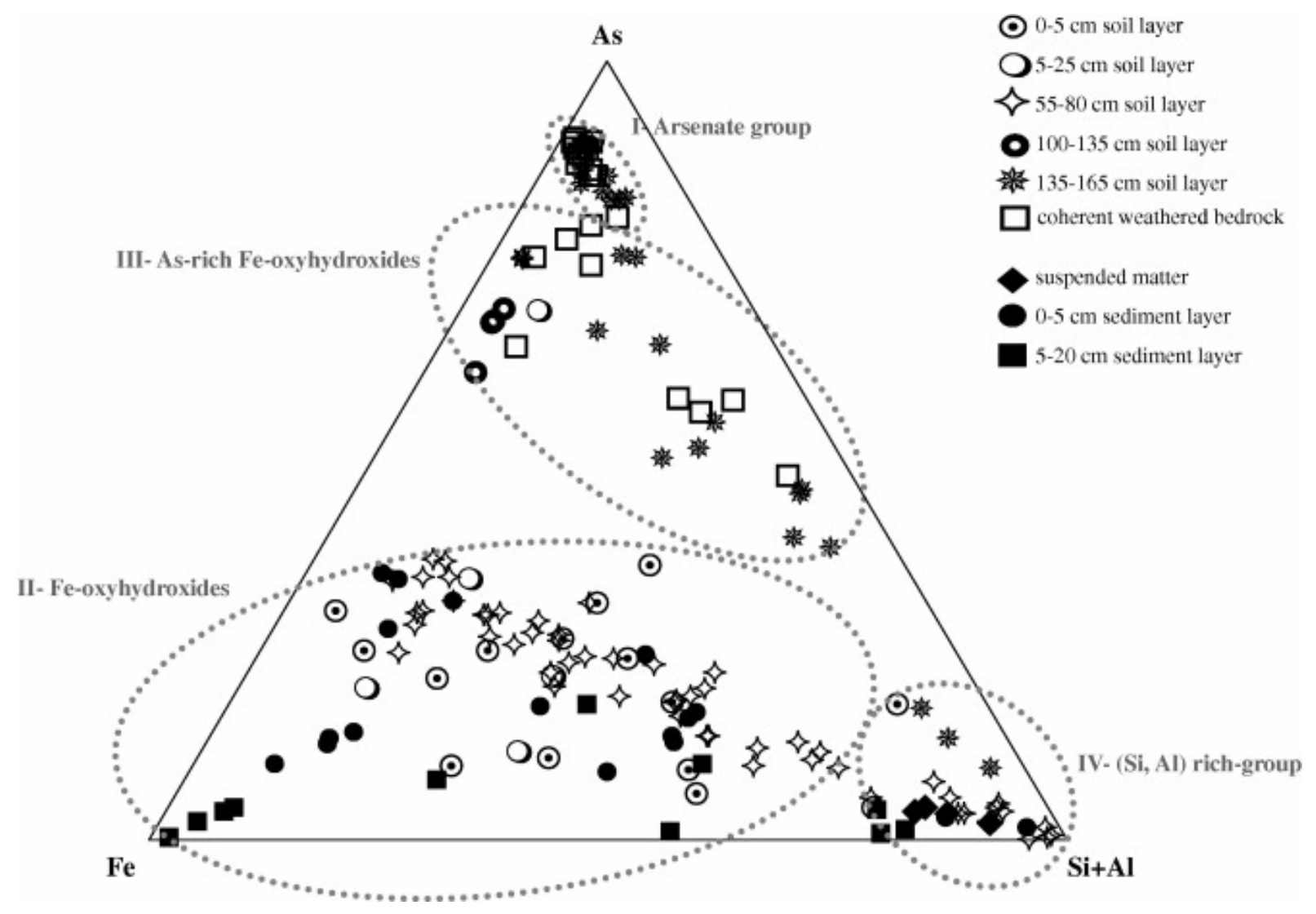

Fig. 6. Log centre ternary diagram of EPMA composition of As-bearing phases identified in the coherent weathered bedrock, soil profile, sediments and suspended matter. 


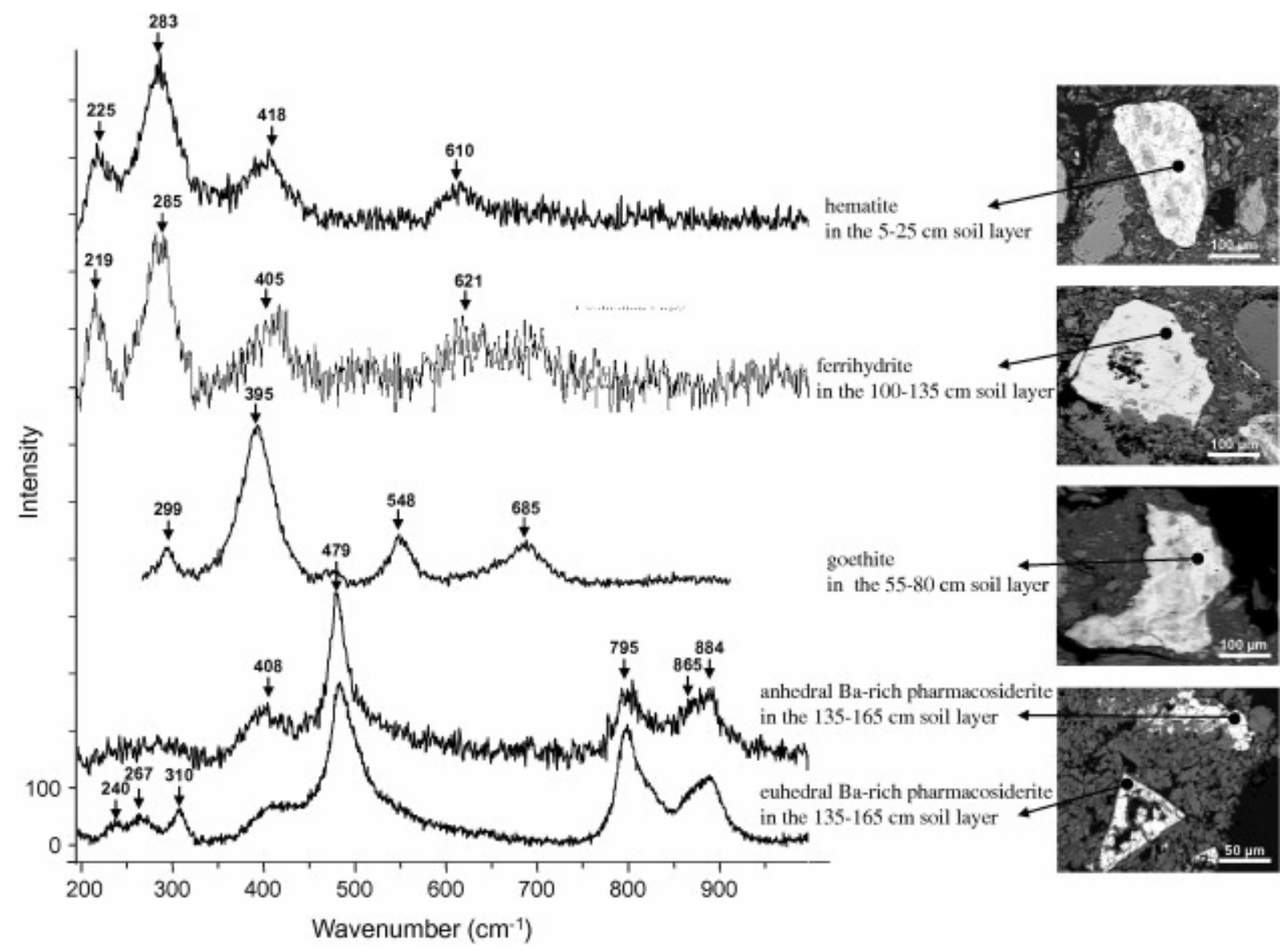

Fig. 7. Micro-Raman spectra and associated BSE images of representative As-bearing phases in the soil profile. 

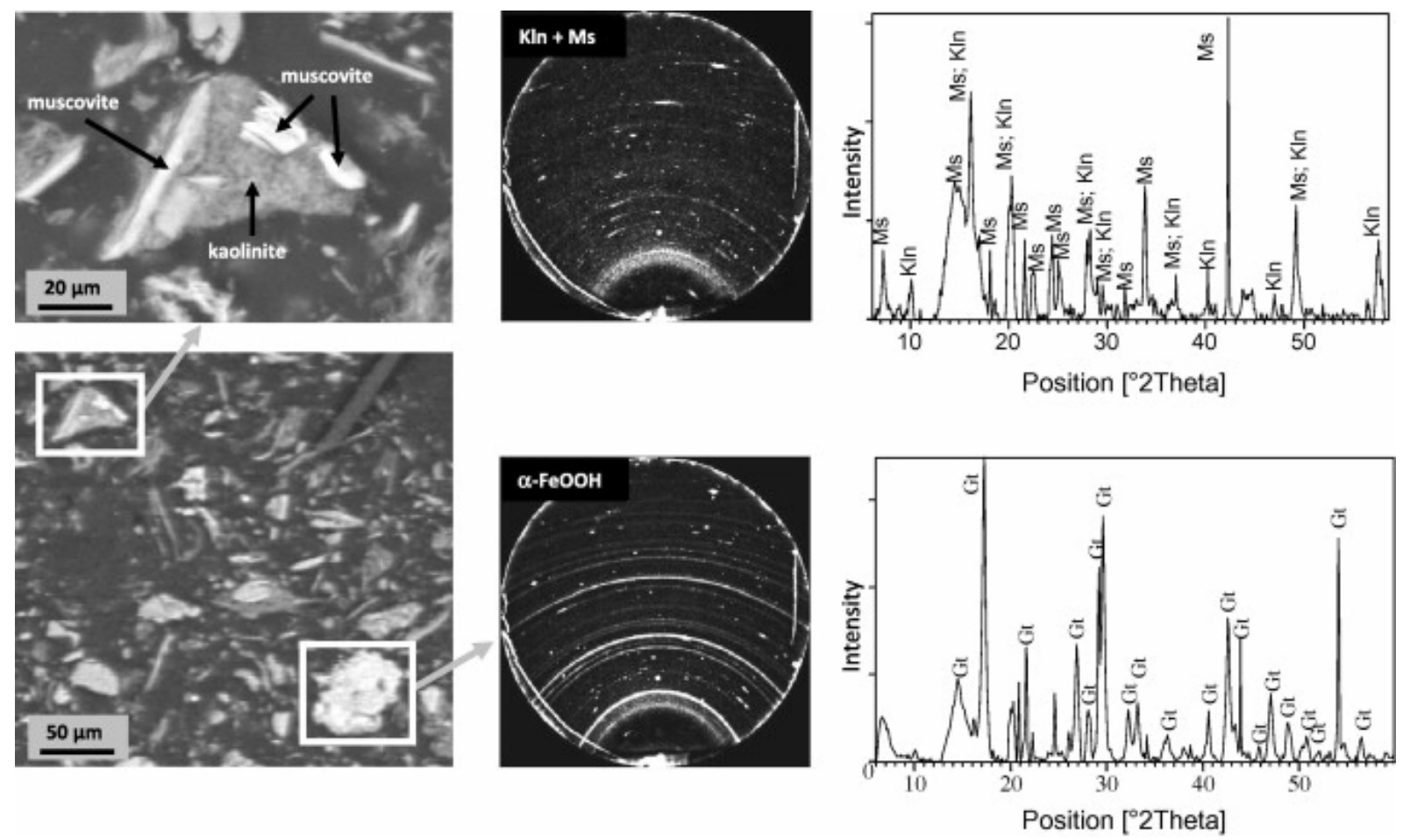

Fig. 8. Representative composite As-bearing phase in the $0-5 \mathrm{~cm}$ sediment layer with BSE image on an aluminosilicate composite particle (group IV), the Debye Scherrer images and integrated $\mu$ XRD pattern along $2 \theta$ on the aluminosilicate grain and a goethite grain below (note the continuous rings in this case in contrast to the one obtained for the kaolinite-muscovite assemblage and the broad reflection at $4.5 \AA$ due to the glass of thin section). Ms: muscovite, Kln: kaolinite, Gt: goethite. 
Table 1. Chemical composition of major $\left(\mathrm{g} \mathrm{kg}^{-1}\right)$ and trace elements $\left(\mathrm{mg} \mathrm{kg}^{-1}\right)$ of the $<63 \mu \mathrm{m}$ fraction of bed sediments, suspended matter, the $<2 \mathrm{~mm}$ fraction of soil layers and coherent weathered bedrock. Sediment geochemical background composition, measured and certified values for standards (BE-N, DS7 and SO-18) are reported. 


\begin{tabular}{|c|c|c|c|c|c|c|c|c|c|c|c|c|c|c|c|}
\hline $\begin{array}{l}\text { Sample } \\
\text { type }\end{array}$ & $\begin{array}{l}\mathrm{Si} \\
\left(\mathrm{g} \mathrm{kg}^{-1}\right)\end{array}$ & $\begin{array}{l}\mathrm{Al} \\
\left(\mathrm{g} \mathrm{kg}^{-1}\right)\end{array}$ & $\begin{array}{l}\mathrm{K} \\
\left(\mathrm{g} \mathrm{kg}^{-1}\right)\end{array}$ & $\begin{array}{l}\mathrm{Fe} \\
\left(\mathrm{g} \mathrm{kg}^{-1}\right)\end{array}$ & $\begin{array}{l}\mathrm{Mg} \\
\left(\mathrm{g} \mathrm{kg}^{-1}\right)\end{array}$ & $\mathrm{Ti}\left(\mathrm{g} \mathrm{kg}^{-1}\right)$ & $\mathrm{Na}\left(\mathrm{g} \mathrm{kg}^{-1}\right)$ & $\mathrm{Ca}\left(\mathrm{g} \mathrm{kg}^{-1}\right)$ & $\begin{array}{l}\mathrm{Mn} \\
\left(\mathrm{mg} \mathrm{kg}^{-1}\right)\end{array}$ & $\begin{array}{l}\text { As } \\
\left(\mathrm{mg} \mathrm{kg}^{-1}\right)\end{array}$ & $\begin{array}{l}\mathbf{P b} \\
\left(\mathrm{mg} \mathrm{kg}^{-1}\right. \\
)\end{array}$ & $\begin{array}{l}\mathrm{Cr} \\
\left(\mathrm{mg} \mathrm{kg}^{-1}\right)\end{array}$ & $\begin{array}{l}\mathrm{Zn} \\
\left(\mathrm{mg} \mathrm{kg}^{-1}\right)\end{array}$ & $\begin{array}{l}\mathrm{Ni} \\
\left(\mathrm{mg} \mathrm{kg}^{-1}\right)\end{array}$ & $\begin{array}{l}\text { Co } \\
\left(\mathrm{mg} \mathrm{kg}^{-1}\right)\end{array}$ \\
\hline $\begin{array}{l}\text { Suspended } \\
\text { matter } \\
\text { (range) }\end{array}$ & - & $22-376$ & $7-20$ & $50-216$ & $3.6-9.0$ & $0.7-3.4$ & $2.8-29.5$ & $4.22-9.87$ & $853-9690$ & $\begin{array}{l}492- \\
11,900\end{array}$ & $50-1180$ & $121-993$ & $135-3050$ & $32.6-135.6$ & $19.5-77.8$ \\
\hline $\begin{array}{l}<63 \mu \mathrm{m} \\
\text { Oxic } \\
\text { sediment }\end{array}$ & 264 & 87 & 26 & 36 & 5.6 & 4.2 & 6.2 & 2.57 & 4160 & 1650 & 55 & 68 & 133 & 28.5 & 33.4 \\
\hline $\begin{array}{l}<63 \mu \mathrm{m} \\
\text { Anoxic } \\
\text { sediment }\end{array}$ & - & 108 & 24 & 35 & 6.7 & 3.4 & 3.2 & 1.57 & 321 & 455 & 82 & 108 & 160 & 35.0 & 13.6 \\
\hline $\begin{array}{l}\text { Sediment } \\
\text { background } \\
\underline{\underline{a}}\end{array}$ & 238 & 86 & 17 & 59 & 13.9 & 9.0 & 9.6 & 12.87 & 1560 & 70 & 37 & 136 & 175 & 55.0 & 25.0 \\
\hline $\begin{array}{l}0-5 \mathrm{~cm} \text { Soil } \\
\text { horizon }\end{array}$ & 274 & 68 & 24 & 13 & 2.1 & 1.9 & 2.7 & $<0.07$ & 87 & 385 & 58 & 20 & 40 & 10.9 & 2.7 \\
\hline $\begin{array}{l}5-25 \mathrm{~cm} \\
\text { Soil horizon }\end{array}$ & 316 & 79 & 27 & 16 & 2.3 & 2.1 & 2.7 & 1.07 & 122 & 589 & 52 & 89 & 22 & 13.0 & 4.0 \\
\hline $\begin{array}{l}25-55 \mathrm{~cm} \\
\text { Soil horizon }\end{array}$ & 303 & 104 & 30 & 17 & 2.1 & 2.0 & 1.6 & 0.79 & 115 & 663 & 66 & 21 & 26 & 13.0 & 4.1 \\
\hline $\begin{array}{l}55-80 \mathrm{~cm} \\
\text { Soil horizon }\end{array}$ & 296 & 112 & 30 & 18 & 1.7 & 1.6 & 0.8 & 0.07 & 76 & 690 & 71 & 41 & 24 & 10.5 & 3.3 \\
\hline $\begin{array}{l}80-100 \mathrm{~cm} \\
\text { Soil horizon }\end{array}$ & 303 & 110 & 33 & 12 & 1.6 & 1.4 & 0.7 & 0.07 & 62 & 450 & 49 & 7 & 15 & $<5.0$ & 2.5 \\
\hline $\begin{array}{l}100- \\
135 \mathrm{~cm} \text { Soil } \\
\text { horizon }\end{array}$ & 309 & 104 & 30 & 14 & 1.7 & 1.4 & 0.7 & 0.07 & 93 & 606 & 78 & 14 & 27 & 8.0 & 3.0 \\
\hline $\begin{array}{l}135- \\
165 \mathrm{~cm} \text { Soil } \\
\text { horizon }\end{array}$ & 306 & 108 & 31 & 13 & 1.8 & 1.5 & 1.3 & 0.43 & 83 & 1490 & 38 & 14 & 10 & 6.5 & 2.6 \\
\hline
\end{tabular}




\begin{tabular}{|c|c|c|c|c|c|c|c|c|c|c|c|c|c|c|c|}
\hline $\begin{array}{l}\text { Sample } \\
\text { type }\end{array}$ & $\begin{array}{l}\mathrm{Si} \\
\left(\mathrm{g} \mathrm{kg}^{-1}\right)\end{array}$ & $\begin{array}{l}\mathrm{Al} \\
\left(\mathrm{g} \mathrm{kg}^{-1}\right)\end{array}$ & $\begin{array}{l}\mathrm{K} \\
\left(\mathrm{g} \mathrm{kg}^{-1}\right)\end{array}$ & $\begin{array}{l}\mathrm{Fe} \\
\left(\mathrm{g} \mathrm{kg}^{-1}\right)\end{array}$ & $\begin{array}{l}\mathrm{Mg} \\
\left(\mathrm{g} \mathrm{kg}^{-1}\right)\end{array}$ & $\mathrm{Ti}\left(\mathrm{g} \mathrm{kg}^{-1}\right)$ & $\mathrm{Na}\left(\mathrm{g} \mathrm{kg}^{-1}\right)$ & $\mathrm{Ca}\left(\mathrm{g} \mathrm{kg}^{-1}\right)$ & $\begin{array}{l}\mathrm{Mn} \\
\left(\mathrm{mg} \mathrm{kg}^{-1}\right)\end{array}$ & $\begin{array}{l}\text { As } \\
\left(\mathrm{mg} \mathrm{kg}^{-1}\right)\end{array}$ & $\begin{array}{l}\mathrm{Pb} \\
\left(\mathrm{mg} \mathrm{kg}^{-1}\right. \\
)\end{array}$ & $\begin{array}{l}\mathrm{Cr} \\
\left(\mathrm{mg} \mathrm{kg}^{-1}\right)\end{array}$ & $\begin{array}{l}\mathrm{Zn} \\
\left(\mathrm{mg} \mathrm{kg}^{-1}\right)\end{array}$ & $\begin{array}{l}\mathrm{Ni} \\
\left(\mathrm{mg} \mathrm{kg}^{-1}\right)\end{array}$ & $\begin{array}{l}\text { Co } \\
\left(\mathrm{mg} \mathrm{kg}^{-1}\right)\end{array}$ \\
\hline Bedrock & 342 & 77 & 44 & 11 & 1.9 & 1.1 & 15.7 & $<0.07$ & 100 & 5660 & 111 & 8 & 21 & $<5.0$ & 1.0 \\
\hline $\mathrm{BE}-\mathrm{N}^{\underline{b}}$ & - & $\begin{array}{l}53 \\
(53 \pm 2 \\
)\end{array}$ & $\begin{array}{l}12 \\
(11 \pm 1 \\
)\end{array}$ & $\begin{array}{l}104 \\
(90 \pm 3 \\
)\end{array}$ & $\begin{array}{l}77.3 \\
(79.3 \pm 2.6 \\
)\end{array}$ & $\begin{array}{l}15.6 \\
(15.6 \pm 0.8 \\
)\end{array}$ & $\begin{array}{l}24.6 \\
(23.6 \pm 1.7 \\
)\end{array}$ & $\begin{array}{l}97.2 \\
(99.2 \pm 2.6 \\
)\end{array}$ & $\begin{array}{l}1560 \\
(1560 \pm 156 \\
)\end{array}$ & $\begin{array}{l}1.8 \\
(1.8 \pm 0.6 \\
)\end{array}$ & $4(4 \pm 2)$ & $\begin{array}{l}333 \\
(360 \pm 49 \\
)\end{array}$ & $\begin{array}{l}120 \\
(120 \pm 50 \\
)\end{array}$ & $\begin{array}{l}267 \\
(267 \pm 26.5 \\
)\end{array}$ & $\begin{array}{l}52.2 \\
(60.0 \pm 7.8 \\
)\end{array}$ \\
\hline $\mathrm{DS} 7^{\underline{\mathrm{b}}}$ & - & - & - & - & - & - & - & - & - & $\begin{array}{l}49 \\
(48 \pm 5)\end{array}$ & $\begin{array}{l}69 \\
(71 \pm 5)\end{array}$ & - & $\begin{array}{l}408 \\
(411 \pm 24 \\
)\end{array}$ & $\begin{array}{l}52.7 \\
(56.0 \pm 4.0)\end{array}$ & - \\
\hline $\mathrm{SO} 18^{\underline{\mathrm{b}}}$ & $\begin{array}{l}72 \\
(274 \pm 8 \\
)\end{array}$ & $\begin{array}{l}75 \\
(75 \pm 2 \\
)\end{array}$ & $\begin{array}{l}18 \\
(18 \pm 1 \\
)\end{array}$ & $\begin{array}{l}53 \\
(54 \pm 1 \\
)\end{array}$ & $\begin{array}{l}20.2 \\
(20.2 \pm 0.6 \\
)\end{array}$ & $\begin{array}{l}4.1 \\
(4.1 \pm 0.2)\end{array}$ & $\begin{array}{l}27.4 \\
(27.5 \pm 0.8 \\
)\end{array}$ & $\begin{array}{l}45.7 \\
(45.9 \pm 1.4 \\
)\end{array}$ & $\begin{array}{l}3000 \\
(3000 \pm 300 \\
)\end{array}$ & - & & & & & \\
\hline
\end{tabular}

${ }^{a}<63 \mu \mathrm{m}$ Bed sediment geochemical backgound determined by Grosbois et al. (2007) in the same basin.

${ }^{b}$ Measured value of reference materials (certified value \pm standard deviation). 
Table 2. Vertical distribution of enrichment factors in the soil profile of elements with $\mathrm{Ti}$ as conservative element and coherent weathered bedrock as reference level.

\begin{tabular}{|c|c|c|c|c|c|c|c|c|c|c|c|c|c|c|c|c|}
\hline Sample & $\mathbf{S i}$ & Al & $\mathrm{Fe}$ & Mg & $\mathbf{N a}$ & $\mathbf{K}$ & $\mathrm{Ca}$ & $\mathbf{T i}$ & As & Co & $\mathrm{Cr}$ & Mn & $\mathrm{Ni}$ & $\mathbf{P b}$ & $\mathbf{Z n}$ & $\mathbf{Z r}$ \\
\hline $\begin{array}{l}0-5 \mathrm{~cm} \\
\text { Soil layer }\end{array}$ & $\begin{array}{l}0.4 \\
7\end{array}$ & $\begin{array}{l}0.5 \\
1\end{array}$ & $\begin{array}{l}0.6 \\
6\end{array}$ & $\begin{array}{l}0.6 \\
2\end{array}$ & $\begin{array}{l}0.1 \\
0\end{array}$ & $\begin{array}{l}0.3 \\
2\end{array}$ & $\begin{array}{l}0.5 \\
8\end{array}$ & $\begin{array}{l}1.0 \\
0\end{array}$ & $\begin{array}{l}0.0 \\
4\end{array}$ & $\begin{array}{l}1.5 \\
7\end{array}$ & $\begin{array}{l}1.4 \\
5\end{array}$ & $\begin{array}{l}0.5 \\
0\end{array}$ & $\begin{array}{l}1.2 \\
7\end{array}$ & $\begin{array}{l}0.3 \\
0\end{array}$ & $\begin{array}{l}1.0 \\
9\end{array}$ & $\begin{array}{l}0.6 \\
8\end{array}$ \\
\hline $\begin{array}{l}5-25 \mathrm{~cm} \\
\text { Soil layer }\end{array}$ & $\begin{array}{l}0.4 \\
8\end{array}$ & $\begin{array}{l}0.5 \\
2\end{array}$ & $\begin{array}{l}0.7 \\
5\end{array}$ & $\begin{array}{l}0.6 \\
1\end{array}$ & $\begin{array}{l}0.0 \\
9\end{array}$ & $\begin{array}{l}0.3 \\
2\end{array}$ & $\begin{array}{l}7.7 \\
1\end{array}$ & $\begin{array}{l}1.0 \\
0\end{array}$ & $\begin{array}{l}0.0 \\
5\end{array}$ & $\begin{array}{l}2.0 \\
6\end{array}$ & $\begin{array}{l}5.7 \\
2\end{array}$ & $\begin{array}{l}0.6 \\
3\end{array}$ & $\begin{array}{l}1.3 \\
4\end{array}$ & $\begin{array}{l}0.2 \\
4\end{array}$ & $\begin{array}{l}0.5 \\
3\end{array}$ & $\begin{array}{l}0.7 \\
4\end{array}$ \\
\hline $\begin{array}{l}25-55 \mathrm{~cm} \\
\text { Soil layer }\end{array}$ & $\begin{array}{l}0.4 \\
8\end{array}$ & $\begin{array}{l}0.7 \\
3\end{array}$ & $\begin{array}{l}0.8 \\
2\end{array}$ & $\begin{array}{l}0.6 \\
0\end{array}$ & $\begin{array}{l}0.0 \\
6\end{array}$ & $\begin{array}{l}0.3 \\
7\end{array}$ & $\begin{array}{l}6.0 \\
0\end{array}$ & $\begin{array}{l}1.0 \\
0\end{array}$ & $\begin{array}{l}0.0 \\
6\end{array}$ & $\begin{array}{l}2.2 \\
4\end{array}$ & $\begin{array}{l}1.4 \\
3\end{array}$ & $\begin{array}{l}0.6 \\
3\end{array}$ & $\begin{array}{l}1.4 \\
2\end{array}$ & $\begin{array}{l}0.3 \\
3\end{array}$ & $\begin{array}{l}0.6 \\
7\end{array}$ & $\begin{array}{l}0.9 \\
3\end{array}$ \\
\hline $\begin{array}{l}55-80 \mathrm{~cm} \\
\text { Soil layer }\end{array}$ & $\begin{array}{l}0.6 \\
0\end{array}$ & $\begin{array}{l}1.0 \\
0\end{array}$ & $\begin{array}{l}1.0 \\
9\end{array}$ & $\begin{array}{l}0.6 \\
1\end{array}$ & $\begin{array}{l}0.0 \\
4\end{array}$ & $\begin{array}{l}0.4 \\
8\end{array}$ & $\begin{array}{l}0.6 \\
9\end{array}$ & $\begin{array}{l}1.0 \\
0\end{array}$ & $\begin{array}{l}0.0 \\
8\end{array}$ & $\begin{array}{l}2.2 \\
9\end{array}$ & $\begin{array}{l}3.5 \\
5\end{array}$ & $\begin{array}{l}0.5 \\
3\end{array}$ & $\begin{array}{l}1.4 \\
5\end{array}$ & $\begin{array}{l}0.4 \\
4\end{array}$ & $\begin{array}{l}0.7 \\
8\end{array}$ & $\begin{array}{l}1.1 \\
3\end{array}$ \\
\hline $\begin{array}{l}80- \\
100 \mathrm{~cm} \\
\text { Soil layer }\end{array}$ & $\begin{array}{l}0.6 \\
7\end{array}$ & $\begin{array}{l}1.0 \\
6\end{array}$ & $\begin{array}{l}0.7 \\
8\end{array}$ & $\begin{array}{l}0.6 \\
1\end{array}$ & $\begin{array}{l}0.0 \\
4\end{array}$ & $\begin{array}{l}0.5 \\
6\end{array}$ & $\begin{array}{l}0.7 \\
5\end{array}$ & $\begin{array}{l}1.0 \\
0\end{array}$ & $\begin{array}{l}0.0 \\
6\end{array}$ & $\begin{array}{l}1.8 \\
7\end{array}$ & $\begin{array}{l}0.6 \\
6\end{array}$ & $\begin{array}{l}0.4 \\
6\end{array}$ & $\begin{array}{l}0.7 \\
5\end{array}$ & $\begin{array}{l}0.3 \\
3\end{array}$ & $\begin{array}{l}0.5 \\
3\end{array}$ & $\begin{array}{l}1.1 \\
4\end{array}$ \\
\hline $\begin{array}{l}100- \\
135 \mathrm{~cm} \\
\text { Soil layer }\end{array}$ & $\begin{array}{l}0.6 \\
8\end{array}$ & $\begin{array}{l}1.0 \\
1\end{array}$ & $\begin{array}{l}0.9 \\
7\end{array}$ & $\begin{array}{l}0.6 \\
6\end{array}$ & $\begin{array}{l}0.0 \\
3\end{array}$ & $\begin{array}{l}0.5 \\
2\end{array}$ & $\begin{array}{l}0.7 \\
5\end{array}$ & $\begin{array}{l}1.0 \\
0\end{array}$ & $\begin{array}{l}0.0 \\
8\end{array}$ & $\begin{array}{l}2.2 \\
5\end{array}$ & $\begin{array}{l}1.3 \\
1\end{array}$ & $\begin{array}{l}0.7 \\
0\end{array}$ & $\begin{array}{l}1.2 \\
0\end{array}$ & $\begin{array}{l}0.5 \\
3\end{array}$ & $\begin{array}{l}0.9 \\
5\end{array}$ & $\begin{array}{l}1.2 \\
0\end{array}$ \\
\hline $\begin{array}{l}135- \\
165 \mathrm{~cm} \\
\text { Soil layer }\end{array}$ & $\begin{array}{l}0.6 \\
4\end{array}$ & $\begin{array}{l}1.0 \\
1\end{array}$ & $\begin{array}{l}0.8 \\
1\end{array}$ & $\begin{array}{l}0.6 \\
7\end{array}$ & $\begin{array}{l}0.0 \\
6\end{array}$ & $\begin{array}{l}0.5 \\
1\end{array}$ & $\begin{array}{l}4.3 \\
2\end{array}$ & $\begin{array}{l}1.0 \\
0\end{array}$ & $\begin{array}{l}0.1 \\
9\end{array}$ & $\begin{array}{l}1.8 \\
7\end{array}$ & $\begin{array}{l}1.2 \\
6\end{array}$ & $\begin{array}{l}0.6 \\
0\end{array}$ & $\begin{array}{l}0.9 \\
4\end{array}$ & $\begin{array}{l}0.2 \\
5\end{array}$ & $\begin{array}{l}0.3 \\
4\end{array}$ & $\begin{array}{l}1.1 \\
8\end{array}$ \\
\hline $\begin{array}{l}\text { Coherent } \\
\text { weathere } \\
\mathrm{d} \text { bedrock }\end{array}$ & $\begin{array}{l}1.0 \\
0\end{array}$ & $\begin{array}{l}1.0 \\
0\end{array}$ & $\begin{array}{l}1.0 \\
0\end{array}$ & $\begin{array}{l}1.0 \\
0\end{array}$ & $\begin{array}{l}1.0 \\
0\end{array}$ & $\begin{array}{l}1.0 \\
0\end{array}$ & $\begin{array}{l}1.0 \\
0\end{array}$ & $\begin{array}{l}1.0 \\
0\end{array}$ & $\begin{array}{l}1.0 \\
0\end{array}$ & $\begin{array}{l}1.0 \\
0\end{array}$ & $\begin{array}{l}1.0 \\
0\end{array}$ & $\begin{array}{l}1.0 \\
0\end{array}$ & $\begin{array}{l}1.0 \\
0\end{array}$ & $\begin{array}{l}1.0 \\
0\end{array}$ & $\begin{array}{l}1.0 \\
0\end{array}$ & $\begin{array}{l}1.0 \\
0\end{array}$ \\
\hline
\end{tabular}

Table 3. Chemical composition of major and trace elements (expressed in wt.\%) of Asbearing phases in coherent weathered bedrock, soil, sediments and suspended matter (in situ EPMA analyses).

\begin{tabular}{|c|c|c|c|c|c|c|c|c|c|c|c|c|c|c|c|}
\hline Sample & $\begin{array}{l}\text { Type of As- } \\
\text { bearing } \\
\text { phases }\end{array}$ & $\begin{array}{l}P \\
\underline{\mathbf{a}}\end{array}$ & $n^{\underline{b}}$ & $\mathbf{S i}$ & Al & $\mathbf{F e}$ & $\mathbf{K}$ & Mg & $\mathbf{T i}$ & $\mathrm{Na}$ & $\mathbf{C a}$ & As & $\mathbf{S}$ & $\mathbf{P}$ & $\begin{array}{l}\text { Tot } \\
\text { al }\end{array}$ \\
\hline $\begin{array}{l}\text { Suspend } \\
\text { ed } \\
\text { matter }\end{array}$ & $\begin{array}{l}\text { Aluminosilic } \\
\text { ate (IV) })^{\mathrm{c}}\end{array}$ & 4 & 9 & $\begin{array}{l}11.7 \\
- \\
16.5\end{array}$ & $\begin{array}{l}4.6- \\
7.9\end{array}$ & $\begin{array}{l}5.2- \\
11.7\end{array}$ & $\begin{array}{l}0.53 \\
- \\
1.15\end{array}$ & $\begin{array}{l}0.28 \\
- \\
0.37\end{array}$ & $\begin{array}{l}0.07 \\
- \\
0.13\end{array}$ & $\begin{array}{l}0.04 \\
- \\
0.11\end{array}$ & $\begin{array}{l}0.36 \\
- \\
0.63\end{array}$ & $\begin{array}{l}0.14 \\
- \\
0.33\end{array}$ & $\begin{array}{l}0.13 \\
- \\
0.17\end{array}$ & $\begin{array}{l}0.12 \\
- \\
0.21\end{array}$ & $\begin{array}{l}51.6 \\
- \\
69.6\end{array}$ \\
\hline \multirow[t]{2}{*}{$\begin{array}{l}0-5 \mathrm{~cm} \\
\text { Sedimen } \\
\text { t layer }\end{array}$} & $\begin{array}{l}\mathrm{Fe}- \\
\text { oxyhydroxid } \\
\text { e (II) })^{\mathrm{c}}\end{array}$ & $\begin{array}{l}1 \\
5\end{array}$ & 49 & $\begin{array}{l}0.4- \\
6.8\end{array}$ & $\begin{array}{l}0.2- \\
5.2\end{array}$ & $\begin{array}{l}12.6 \\
- \\
47.8\end{array}$ & $\begin{array}{l}0.00 \\
- \\
1.69\end{array}$ & $\begin{array}{l}0.07 \\
- \\
0.57\end{array}$ & $\begin{array}{l}0.00 \\
- \\
0.10\end{array}$ & $\begin{array}{l}0.00 \\
- \\
0.16\end{array}$ & $\begin{array}{l}0.12 \\
- \\
1.18\end{array}$ & $\begin{array}{l}0.41 \\
- \\
2.25\end{array}$ & $\begin{array}{l}0.01 \\
- \\
0.41\end{array}$ & $\begin{array}{l}0.03 \\
- \\
0.77\end{array}$ & $\begin{array}{l}43.1 \\
- \\
78.7\end{array}$ \\
\hline & $\begin{array}{l}\text { Aluminosilic } \\
\text { ate (IV) }\end{array}$ & 2 & 5 & $\begin{array}{l}16.2 \\
- \\
19.5\end{array}$ & $\begin{array}{l}6.4- \\
11.7\end{array}$ & $\begin{array}{l}2.9 \\
11.9\end{array}$ & $\begin{array}{l}0.09 \\
- \\
2.31\end{array}$ & $\begin{array}{l}0.06 \\
- \\
0.67\end{array}$ & $\begin{array}{l}0.00 \\
- \\
0.12\end{array}$ & $\begin{array}{l}0.15 \\
- \\
5.55\end{array}$ & $\begin{array}{l}0.49 \\
- \\
0.67\end{array}$ & $\begin{array}{l}0.13 \\
- \\
0.27\end{array}$ & $\begin{array}{l}0.03 \\
- \\
0.11\end{array}$ & $\begin{array}{l}0.03 \\
- \\
0.26\end{array}$ & $\begin{array}{l}66.8 \\
- \\
78.4\end{array}$ \\
\hline $\begin{array}{l}5-20 \mathrm{~cm} \\
\text { Sedimen } \\
t \text { layer }\end{array}$ & $\begin{array}{l}\mathrm{Fe}- \\
\text { oxyhydroxid } \\
\text { e (II) })^{\mathrm{c}}\end{array}$ & 8 & 17 & $\begin{array}{l}0.1- \\
8.2\end{array}$ & $\begin{array}{l}0.3- \\
7.5\end{array}$ & $\begin{array}{l}25.1 \\
- \\
75.5\end{array}$ & $\begin{array}{l}0.00 \\
- \\
2.11\end{array}$ & $\begin{array}{l}0.04 \\
- \\
0.19\end{array}$ & $\begin{array}{l}0.01 \\
- \\
0.31\end{array}$ & $\begin{array}{l}0.01 \\
- \\
0.20\end{array}$ & $\begin{array}{l}0.07 \\
- \\
1.33\end{array}$ & $\begin{array}{l}0.04 \\
- \\
0.87\end{array}$ & $\begin{array}{l}0.01 \\
- \\
0.17\end{array}$ & $\begin{array}{l}0.01 \\
- \\
0.82\end{array}$ & $\begin{array}{l}51.3 \\
- \\
98.8\end{array}$ \\
\hline
\end{tabular}




\begin{tabular}{|c|c|c|c|c|c|c|c|c|c|c|c|c|c|c|c|}
\hline Sample & $\begin{array}{l}\text { Type of As- } \\
\text { bearing } \\
\text { phases }\end{array}$ & $\begin{array}{l}\boldsymbol{P} \\
\underline{\mathrm{a}}\end{array}$ & $n^{\underline{b}}$ & $\mathbf{S i}$ & Al & $\mathbf{F e}$ & $\mathbf{K}$ & Mg & $\mathbf{T i}$ & $\mathbf{N a}$ & $\mathbf{C a}$ & As & $\mathbf{S}$ & $\mathbf{P}$ & $\begin{array}{l}\text { Tot } \\
\text { al }\end{array}$ \\
\hline & $\begin{array}{l}\text { Aluminosilic } \\
\text { ate }(I V)^{\underline{c}}\end{array}$ & 3 & 4 & $\begin{array}{l}13.3 \\
- \\
14.5\end{array}$ & $\begin{array}{l}10.7 \\
- \\
11.9\end{array}$ & $\begin{array}{l}16.2 \\
- \\
19.9\end{array}$ & $\begin{array}{l}0.16 \\
- \\
3.56\end{array}$ & $\begin{array}{l}0.21 \\
- \\
0.85\end{array}$ & $\begin{array}{l}0.01 \\
- \\
0.20\end{array}$ & $\begin{array}{l}0.05 \\
- \\
0.08\end{array}$ & $\begin{array}{l}0.21 \\
- \\
0.51\end{array}$ & $\begin{array}{l}0.09 \\
- \\
0.37\end{array}$ & $\begin{array}{l}0.02 \\
- \\
0.08\end{array}$ & $\begin{array}{l}0.07 \\
- \\
0.31\end{array}$ & $\begin{array}{l}73.3 \\
- \\
85.9\end{array}$ \\
\hline \multirow[t]{3}{*}{$\begin{array}{l}0-5 \mathrm{~cm} \\
\text { Soil } \\
\text { layer }\end{array}$} & Arsenate $(\mathrm{I})^{\mathrm{c}}$ & 1 & 3 & $\begin{array}{l}0.4- \\
0.8\end{array}$ & $\begin{array}{l}1.9- \\
2.7\end{array}$ & $\begin{array}{l}18.2 \\
- \\
20.4\end{array}$ & $\begin{array}{l}0.44 \\
- \\
0.52\end{array}$ & $\begin{array}{l}0.01 \\
- \\
0.07\end{array}$ & $\begin{array}{l}0.00 \\
- \\
0.03\end{array}$ & $\begin{array}{l}0.00 \\
- \\
0.17\end{array}$ & $\begin{array}{l}0.01 \\
- \\
0.14\end{array}$ & $\begin{array}{l}20.2 \\
- \\
26.0\end{array}$ & $\begin{array}{l}0.01 \\
- \\
0.14\end{array}$ & $\begin{array}{l}0.04 \\
- \\
0.09\end{array}$ & $\begin{array}{l}66.4 \\
- \\
79.4\end{array}$ \\
\hline & $\begin{array}{l}\text { Fe- } \\
\text { oxyhydroxid } \\
\text { e (II) })^{\mathrm{c}}\end{array}$ & $\begin{array}{l}1 \\
3\end{array}$ & 29 & $\begin{array}{l}0.3- \\
8.8\end{array}$ & $\begin{array}{l}0.9- \\
7.2\end{array}$ & $\begin{array}{l}21.2 \\
- \\
47.1\end{array}$ & $\begin{array}{l}0.03 \\
- \\
1.16\end{array}$ & $\begin{array}{l}0.01 \\
- \\
0.43\end{array}$ & $\begin{array}{l}0.00 \\
- \\
0.67\end{array}$ & $\begin{array}{l}0.00 \\
- \\
0.20\end{array}$ & $\begin{array}{l}0.06 \\
- \\
0.52\end{array}$ & $\begin{array}{l}0.31 \\
- \\
3.06\end{array}$ & $\begin{array}{l}0.05 \\
- \\
0.31\end{array}$ & $\begin{array}{l}0.16 \\
- \\
0.57\end{array}$ & $\begin{array}{l}52.9 \\
- \\
73.7\end{array}$ \\
\hline & $\begin{array}{l}\text { Aluminosilic } \\
\text { ate }(I V)^{\underline{c}}\end{array}$ & 2 & 4 & $\begin{array}{l}10.3 \\
- \\
15.0\end{array}$ & $\begin{array}{l}5.0 \\
13.8\end{array}$ & $\begin{array}{l}11.8 \\
- \\
11.9\end{array}$ & $\begin{array}{l}0.13 \\
- \\
0.50\end{array}$ & $\begin{array}{l}0.06 \\
- \\
0.16\end{array}$ & $\begin{array}{l}0.21 \\
- \\
0.28\end{array}$ & $\begin{array}{l}0.01 \\
- \\
0.03\end{array}$ & $\begin{array}{l}0.20 \\
- \\
0.27\end{array}$ & $\begin{array}{l}0.24 \\
- \\
1.88\end{array}$ & $\begin{array}{l}0.34 \\
- \\
0.51\end{array}$ & $\begin{array}{l}0.11 \\
- \\
0.12\end{array}$ & $\begin{array}{l}50.3 \\
- \\
79.3\end{array}$ \\
\hline \multirow[t]{2}{*}{$\begin{array}{l}5-25 \mathrm{~cm} \\
\text { Soil } \\
\text { layer }\end{array}$} & $\begin{array}{l}\text { As-rich Fe- } \\
\text { oxydroxide } \\
\text { (III) }^{\mathrm{c}}\end{array}$ & 1 & 2 & $\begin{array}{l}0.5- \\
1.9\end{array}$ & $\begin{array}{l}2.8- \\
3.7\end{array}$ & $\begin{array}{l}38.1 \\
- \\
41.3\end{array}$ & $\begin{array}{l}0.05 \\
- \\
0.16\end{array}$ & $\begin{array}{l}0.00 \\
- \\
0.07\end{array}$ & $\begin{array}{l}0.21 \\
- \\
0.26\end{array}$ & $\begin{array}{l}0.00 \\
- \\
0.09\end{array}$ & $\begin{array}{l}0.11 \\
- \\
0.14\end{array}$ & $\begin{array}{l}9.04 \\
- \\
10.8\end{array}$ & $\begin{array}{l}0.01 \\
- \\
0.09\end{array}$ & $\begin{array}{l}0.08 \\
- \\
0.12\end{array}$ & $\begin{array}{l}75.8 \\
- \\
77.7\end{array}$ \\
\hline & $\begin{array}{l}\text { Fe- } \\
\text { oxyhydroxid } \\
\text { e (II) }\end{array}$ & 4 & 12 & $\begin{array}{l}0.6- \\
4.2\end{array}$ & $\begin{array}{l}3.0- \\
6.6\end{array}$ & $\begin{array}{l}39.0 \\
- \\
54.4\end{array}$ & $\begin{array}{l}0.09 \\
- \\
0.31\end{array}$ & $\begin{array}{l}0.00 \\
- \\
0.20\end{array}$ & $\begin{array}{l}0.06 \\
- \\
0.58\end{array}$ & $\begin{array}{l}0.06 \\
- \\
0.13\end{array}$ & $\begin{array}{l}0.04 \\
- \\
0.15\end{array}$ & $\begin{array}{l}0.80 \\
- \\
2.35\end{array}$ & $\begin{array}{l}0.02 \\
- \\
0.05\end{array}$ & $\begin{array}{l}0.16 \\
- \\
0.57\end{array}$ & $\begin{array}{l}64.7 \\
- \\
81.2\end{array}$ \\
\hline \multirow[t]{2}{*}{$\begin{array}{l}55- \\
80 \mathrm{~cm} \\
\text { Soil } \\
\text { layer }\end{array}$} & $\begin{array}{l}\text { Fe- } \\
\text { oxyhydroxid } \\
\text { e (II) }\end{array}$ & $\begin{array}{l}4 \\
1\end{array}$ & $\begin{array}{l}11 \\
4\end{array}$ & $\begin{array}{l}0.3- \\
14.9\end{array}$ & $\begin{array}{l}1.7- \\
11.3\end{array}$ & $\begin{array}{l}21.3 \\
- \\
49.8\end{array}$ & $\begin{array}{l}0.00 \\
- \\
2.35\end{array}$ & $\begin{array}{l}0.00 \\
- \\
0.44\end{array}$ & $\begin{array}{l}0.00 \\
- \\
0.42\end{array}$ & $\begin{array}{l}0.00 \\
- \\
0.18\end{array}$ & $\begin{array}{l}0.05 \\
- \\
0.26\end{array}$ & $\begin{array}{l}0.87 \\
- \\
3.06\end{array}$ & $\begin{array}{l}0.00 \\
- \\
0.17\end{array}$ & $\begin{array}{l}0.08 \\
- \\
0.76\end{array}$ & $\begin{array}{l}57.7 \\
- \\
84.6\end{array}$ \\
\hline & $\begin{array}{l}\text { Aluminosilic } \\
\text { ate }(\mathrm{IV})^{\mathrm{c}}\end{array}$ & $\begin{array}{l}1 \\
3\end{array}$ & 29 & $\begin{array}{l}11.3 \\
- \\
20.5\end{array}$ & $\begin{array}{l}11.0 \\
- \\
17.2\end{array}$ & $\begin{array}{l}1.4- \\
16.9\end{array}$ & $\begin{array}{l}0.04 \\
- \\
7.22\end{array}$ & $\begin{array}{l}0.03 \\
- \\
0.88\end{array}$ & $\begin{array}{l}0.01 \\
- \\
4.32\end{array}$ & $\begin{array}{l}0.01 \\
- \\
0.14\end{array}$ & $\begin{array}{l}0.01 \\
- \\
0.10\end{array}$ & $\begin{array}{l}0.04 \\
- \\
0.73\end{array}$ & $\begin{array}{l}0.00 \\
- \\
0.18\end{array}$ & $\begin{array}{l}0.00 \\
- \\
0.24\end{array}$ & $\begin{array}{l}65.7 \\
- \\
82.0\end{array}$ \\
\hline $\begin{array}{l}100- \\
135 \mathrm{~cm} \\
\text { Soil } \\
\text { layer }\end{array}$ & $\begin{array}{l}\text { As-rich Fe- } \\
\text { oxydroxide } \\
(\text { III) }\end{array}$ & 4 & 9 & $\begin{array}{l}0.6- \\
0.7\end{array}$ & $\begin{array}{l}1.4- \\
1.8\end{array}$ & $\begin{array}{l}49.1 \\
- \\
51.5\end{array}$ & $\begin{array}{l}0.02 \\
- \\
0.05\end{array}$ & $\begin{array}{l}0.00 \\
- \\
0.01\end{array}$ & $\begin{array}{l}0.03 \\
- \\
0.05\end{array}$ & $\begin{array}{l}0.01 \\
- \\
0.04\end{array}$ & $\begin{array}{l}0.08 \\
- \\
0.13\end{array}$ & $\begin{array}{l}7.79 \\
- \\
10.6\end{array}$ & $\begin{array}{l}0.02 \\
- \\
0.05\end{array}$ & $\begin{array}{l}0.06 \\
- \\
0.08\end{array}$ & $\begin{array}{l}83.1 \\
- \\
85.1\end{array}$ \\
\hline \multirow[t]{3}{*}{$\begin{array}{l}135- \\
165 \mathrm{~cm} \\
\text { Soil } \\
\text { layer }\end{array}$} & Arsenate $(\mathrm{I})^{\underline{\mathrm{c}}}$ & $\begin{array}{l}1 \\
2\end{array}$ & 25 & $\begin{array}{l}0.4- \\
3.4\end{array}$ & $\begin{array}{l}14- \\
4.1\end{array}$ & $\begin{array}{l}14.4 \\
- \\
24.5\end{array}$ & $\begin{array}{l}0.18 \\
- \\
0.66\end{array}$ & $\begin{array}{l}0.00 \\
- \\
0.10\end{array}$ & $\begin{array}{l}0.00 \\
- \\
0.02\end{array}$ & $\begin{array}{l}0.00 \\
- \\
0.18\end{array}$ & $\begin{array}{l}0.07 \\
- \\
0.17\end{array}$ & $\begin{array}{l}14.2 \\
- \\
22.1\end{array}$ & $\begin{array}{l}0.00 \\
- \\
0.13\end{array}$ & $\begin{array}{l}0.04 \\
- \\
0.67\end{array}$ & $\begin{array}{l}57.7 \\
- \\
70.7\end{array}$ \\
\hline & $\begin{array}{l}\text { As-rich Fe- } \\
\text { oxydroxide } \\
\text { (III) }\end{array}$ & $\begin{array}{l}1 \\
4\end{array}$ & 25 & $\begin{array}{l}0.2- \\
13.6\end{array}$ & $\begin{array}{l}1.1- \\
11.3\end{array}$ & $\begin{array}{l}8.6- \\
33.5\end{array}$ & $\begin{array}{l}0.04 \\
- \\
2.44\end{array}$ & $\begin{array}{l}0.02 \\
- \\
0.38\end{array}$ & $\begin{array}{l}0.00 \\
- \\
0.10\end{array}$ & $\begin{array}{l}0.00 \\
- \\
0.15\end{array}$ & $\begin{array}{l}0.04 \\
- \\
0.23\end{array}$ & $\begin{array}{l}4.07 \\
- \\
15.4\end{array}$ & $\begin{array}{l}0.00 \\
- \\
0.14\end{array}$ & $\begin{array}{l}0.04 \\
- \\
0.53\end{array}$ & $\begin{array}{l}52.9 \\
- \\
74.3\end{array}$ \\
\hline & $\begin{array}{l}\text { Aluminosilic } \\
\text { ate }(\mathrm{IV})^{\mathrm{c}}\end{array}$ & 3 & 7 & $\begin{array}{l}15.9 \\
- \\
18.5\end{array}$ & $\begin{array}{l}12.2 \\
- \\
15.9\end{array}$ & $\begin{array}{l}4.7- \\
8.8\end{array}$ & $\begin{array}{l}0.07 \\
- \\
2.86\end{array}$ & $\begin{array}{l}0.27 \\
- \\
0.50\end{array}$ & $\begin{array}{l}0.00 \\
- \\
0.01\end{array}$ & $\begin{array}{l}0.01 \\
- \\
0.06\end{array}$ & $\begin{array}{l}0.03 \\
- \\
0.11\end{array}$ & $\begin{array}{l}1.00 \\
- \\
1.79\end{array}$ & $\begin{array}{l}0.03 \\
- \\
0.19\end{array}$ & $\begin{array}{l}0.02 \\
- \\
0.04\end{array}$ & $\begin{array}{l}74.2 \\
- \\
80.5\end{array}$ \\
\hline \multirow[t]{2}{*}{$\begin{array}{l}\text { Coheren } \\
\text { t } \\
\text { weather } \\
\text { ed } \\
\text { bedrock }\end{array}$} & Arsenate $(I)^{\underline{c}}$ & $\begin{array}{l}1 \\
2\end{array}$ & 29 & $\begin{array}{l}0.1- \\
4.6\end{array}$ & $\begin{array}{l}0.9- \\
4.1\end{array}$ & $\begin{array}{l}20.2 \\
- \\
26.8\end{array}$ & $\begin{array}{l}0.24 \\
- \\
1.46\end{array}$ & $\begin{array}{l}0.00 \\
- \\
0.01\end{array}$ & $\begin{array}{l}0.00 \\
- \\
2.23\end{array}$ & $\begin{array}{l}0.03 \\
- \\
0.56\end{array}$ & $\begin{array}{l}0.08 \\
- \\
0.31\end{array}$ & $\begin{array}{l}17.4 \\
- \\
24.7\end{array}$ & $\begin{array}{l}0.00 \\
- \\
0.02\end{array}$ & $\begin{array}{l}0.28 \\
- \\
1.00\end{array}$ & $\begin{array}{l}71.8 \\
- \\
85.0\end{array}$ \\
\hline & $\begin{array}{l}\text { As-rich Fe- } \\
\text { oxydroxide } \\
\text { (III) }^{\mathrm{c}}\end{array}$ & 9 & 16 & $\begin{array}{l}0.6- \\
14.6\end{array}$ & $\begin{array}{l}1.7- \\
12.4\end{array}$ & $\begin{array}{l}12.3 \\
- \\
47.6\end{array}$ & $\begin{array}{l}0.11 \\
- \\
1.27\end{array}$ & $\begin{array}{l}0.00 \\
- \\
0.14\end{array}$ & $\begin{array}{l}0.00 \\
- \\
0.08\end{array}$ & $\begin{array}{l}0.07 \\
- \\
4.09\end{array}$ & $\begin{array}{l}0.14 \\
- \\
0.45\end{array}$ & $\begin{array}{l}7.03 \\
- \\
16.2\end{array}$ & $\begin{array}{l}0.00 \\
- \\
0.11\end{array}$ & $\begin{array}{l}0.23 \\
-0 .\end{array}$ & \\
\hline
\end{tabular}


